\title{
Effects of the depletion of whey proteins from unconcentrated milk using microfiltration on the yield, functionality, and nutritional profile of Cheddar cheese
}

\author{
E. Reale, ${ }^{1}$ S. Govindasamy-Lucey, ${ }^{2} \odot$ M. E. Johnson, ${ }^{2} \odot$ J. J. Jaeggi, ${ }^{2}$ M. Molitor, ${ }^{2}{ }^{\text {Y. }}$ Lu, ${ }^{2} \odot$ and J. A. Lucey ${ }^{2 *} \odot$ \\ ${ }^{1}$ Department of Food Science, University of Wisconsin-Madison 53706 \\ ${ }^{2}$ Center for Dairy Research, University of Wisconsin-Madison 53706
}

\section{ABSTRACT}

Some European dairies use low concentration factor microfiltration $(\mathrm{MF})$ in their cheese plants. Removal of whey protein (WP) from milk before cheesemaking using microfiltration without concentration provides the opportunity to produce a value-added by-product, milk-derived whey. However, few studies have focused on the effects on cheese properties caused by the depletion of WP from cheese milk. Most studies have concentrated cheese milk using MF in addition to depletion of WP. In our approach, cheese milk was not concentrated during WP depletion using MF. We wanted to quantify residual WP levels in cheese made from MF milk and to explore whether WP depletion from milk would influence functionality, nutritional profile, and cheese quality during ripening. Casein $(\mathrm{CN})$ contents for all milks were kept at $\sim 2.5 \%$, to eliminate the confounding factor of concentration of $\mathrm{CN}$, which was observed in some previous MF studies. Cheese milks had similar ratios of $\mathrm{CN}$ to fat. Three standardized milks were produced with various CN:true protein (TP) ratios: (a) control with a CN:TP ratio of $83: 100$, (b) $35 \%$ WP depletion, 89:100 CN:TP, and (c) 70\% WP depletion, 95:100 CN:TP. Cheddar cheeses were made from MF milk with various WP depletion levels and aged for 9 mo, and their functionality was evaluated during ripening. We found no major differences in cheese composition or $\mathrm{pH}$ values between samples. Cheese yield, solids recovery, and nitrogen recovery were slightly higher in the 95:100 CN:TP cheeses compared with the control. These enhanced recoveries reflect that MF-treated milk started with a higher fraction of CN-based protein solids, rather than WP solids. The standardized milk from the 95:100 CN:TP treatment also had a slightly higher fat content compared with the control, likely

Received April 14, 2020

Accepted June 28, 2020.

*Corresponding author: jlucey@cdr.wisc.edu helping to increase cheese yield. Rheological properties of cheeses during heating were similar between treatments. Hardness initially decreased with age for all cheeses due to proteolysis or solubilization, or both, of calcium phosphate. Maximum loss tangent (LT), an index of cheese meltability, was slightly lower for the control cheese until $30 \mathrm{~d}$ of ripening, but after $30 \mathrm{~d}$, all treatments exhibited similar maximum LT values. The temperature where LT $=1$ (crossover temperature), an index of softening point during heating, was slightly lower for MF cheese compared with the control cheeses during ripening. Microfiltration treatment had no significant influence on proteolysis. Sensory properties were similar between the cheeses, except for bitterness. Bitterness intensity was slightly lower in the MF cheeses than in the control cheeses and increased in all cheeses during ripening. We detected no major differences in the concentrations of key nutrients or vitamins between the various cheeses. Depletion of WP in cheese milk by MF did not negatively affect cheese quality, or its nutritional profile, and resulted in similar cheesemaking yields.

Key words: membrane filtration, functionality, cheese quality, cheese ripening

\section{INTRODUCTION}

The commercialization of membranes for separation purposes, specifically the purification of water, began in the 1930s (Pouliot, 2008). Since then, the applications for membrane filtration have been greatly expanded upon. Membrane filtration, specifically microfiltration (MF), initially gained popularity in the dairy industry in the 1980s with the development of ceramic membranes. Microfiltration has become industrially feasible due to technological advancements, such as uniform and low transmembrane pressure (Saboya and Maubois, 2000), as well as the development of polymeric membrane materials with spiral-wound configurations (Govindasamy-Lucey et al., 2007). These advancements have pushed forward the valorization of MF in the 
dairy industry. Microfiltration can be used for various purposes, such as removal of bacteria, preconcentration of cheese milk, fractionation of macronutrients, separation of proteins, and concentration of whey for further processing.

An MF membrane with a pore size of approximately 0.1 to $0.2 \mu \mathrm{m}$ is small enough to retain most $\mathrm{CN}$ and nearly all fat, yet wide enough to allow most whey proteins (WP), lactose, and water to permeate (Ardisson-Korat and Rizvi, 2004). For this reason, MF is a useful tool for the separation of WP from $\mathrm{CN}$. The MF permeate, or milk-derived whey, is valuable because it contains a high concentration of native WP, is virtually sterile, and has consistent composition (not variable due to differences in cheesemaking conditions). Additionally, milk-derived whey does not contain residual cheesemaking ingredients or glycomacropeptide (because milk has not been renneted), whereas traditional cheese whey does (Coppola et al., 2014). Traditional cheese whey can have some limitations on its functionality for further applications due to the presence of residual cheesemaking ingredients. These cheese ingredients (e.g., residual fats, rennet, starter culture, color) may cause limitations, such as the presence of off-flavors, reduced functionality (Coppola et al., 2014), and the necessity for bleaching colored whey if white whey products are desired from colored cheese variants (Campbell et al., 2013). Several studies (Heino et al., 2007; Coppola et al., 2014) compared WP concentrate made from milk-derived whey to that made from traditional cheese whey and reported that the milk-derived whey produced WP concentrate with superior sensory, foaming, and storage properties.

Some studies have examined the use of MF to produce cheese milks, with both high and low concentration factors. Brandsma and Rizvi (1999) used MF to concentrate skim milk to $8-9 \times$ (without diafiltration, DF), and although permeation of WP occurred during MF, the final retentate still contained $2.2 \% \mathrm{WP}$. Brandsma and Rizvi (1999) indicated that this level of residual WP could significantly influence cheesemaking properties and quality. Low concentration factor MF milk can result in milks with WP contents similar to or higher than that of a control milk, due to the concentration of milk solids, even though some WP depletion occurs. For example, Neocleous et al. (2002a) studied the effects of low concentration factor (1.26 to $1.82 \times$ ) MF milk on the yield and quality of Cheddar cheese. The WP concentration in the control and $1.82 \times$ concentrated MF milks were 0.52 and $0.59 \%$, respectively (Neocleous et al., 2002a). They also found that MF concentrated cheese milks produced cheeses with slower proteolysis compared with the control (Neocleous et al., 2002b). Cheddar cheese made using UF-concentrated milks also tend to ripen more slowly than those made from unconcentrated milks (Green et al., 1981). This reduced rate of proteolysis in cheese made from concentrated milk could be due to the increased residual WP concentrations inhibiting chymosin (Creamer et al., 1987; Lelievre and Lawrence, 1988; Harper et al., 1989) or reducing plasmin activity (Bech, 1993).

Nelson and Barbano (2005a) described an MF process to maximize the removal of WP from skim milk. This process involved MF of milk, UF of MF permeate, and DF of MF retentate with UF permeate. This process successfully removed most of the WP originally found in the skim milk. Nelson and Barbano (2005b) manufactured Cheddar cheese from MF milks with various levels of WP but similar low CN levels. They reported that, although the composition of the cheeses made from the 3 treatments was similar, the percentage recoveries of milk solids, protein, and fat increased in the low-WP treatment. The increased solids and protein recoveries in the low-WP treatment was expected because CN made up a higher proportion of the solids in this treatment (instead of WP, which are mostly lost during cheesemaking). The reason for the higher fat recovery in the low-WP treatment was unclear (Nelson and Barbano, 2005b). They also found that cheese made from milk containing low WP had greater proteolysis than the control or high-WP treatments.

However, Nelson and Barbano (2005b) did not evaluate the influence of WP depletion on the texture, sensory, or rheological behavior of Cheddar cheeses. Additionally, Nelson and Barbano (2005b) did not directly measure the WP recovery content in their cheeses. The FDA (2005) has raised questions about whether the use of MF processing of cheese milk would alter the composition of cheese (presumably believing that MF would result in less retention of WP as well as loss of nutrients such as minerals and vitamins). Water-soluble vitamins and small components may permeate the MF membrane, but it is unclear whether these materials would be mostly lost in the cheese whey anyway during the normal drainage step. Little data is available on the effects of MF treatment of cheese milk on the nutritional profile of cheese.

The objective of this study was to use MF to deplete WP from cheese milk without concentrating it, to eliminate concentration factor as a confounding variable. To prevent changes in the soluble phase of milk, DF was carried out during the MF process; the MF retentate was subjected to DF with UF permeate. We explored the influence of WP-depleted milks on the quality, texture, functionality, sensory, and nutritional profiles of Cheddar cheese. 


\section{MATERIALS AND METHODS}

\section{Membrane Processing and Milk Standardization}

A total of 5 trials were performed to remove WP via MF from the cheese milk without concentrating the CN content. For each trial, whole milk was collected from the University of Wisconsin-Madison Dairy Plant. Whole milk was pasteurized at $73^{\circ} \mathrm{C}$ for $19 \mathrm{~s}$ and cooled to $23^{\circ} \mathrm{C}$, and then $\mathrm{MF}$ was used with extensive $\mathrm{DF}$ to significantly deplete the WP. Each trial yielded 1 control milk and 2 experimental milks of differing CNto-true protein (TP) ratios (89:100 CN:TP and 95:100 $\mathrm{CN}$ :TP, respectively). The control milk had a CN-toTP ratio of $83: 100$, which is similar to standard cheese milks used for Cheddar cheese manufacture.

Two Synder Filtration MF elements (model V0.22B-8038, Vacaville, CA) were used in parallel. The membranes were polyvinylidene fluoride-based materials with a spiral-wound configuration. They were 203.2 $\mathrm{mm}$ in diameter and $965.2 \mathrm{~mm}$ long, yielding approximately $68.4 \mathrm{~m}^{2}$ total membrane area. The feed spacer was $0.8 \mathrm{~mm}$ thick. The nominal pore sizes were around 0.2 microns. The MF system was run at about $23^{\circ} \mathrm{C}$ with an average flux of about $14 \mathrm{~L} / \mathrm{min}$ and inlet and outlet pressures of around 110.3 and $25.5 \mathrm{kPa}$, respectively.

Six Synder Filtration UF elements (model ST3B-4338) were used within 3 parallel vessels, each containing 2 elements. The membranes were polyethersulfone-based material with a spiral-wound configuration. They were $109.2 \mathrm{~mm}$ in diameter and $965.2 \mathrm{~mm}$ long, yielding $43.2 \mathrm{~m}^{2}$ total membrane area. The feed spacer was $1.17 \mathrm{~mm}$ in thickness, and the molecular weight cutoff was $10 \mathrm{kDa}$. The UF system was run at about $23^{\circ} \mathrm{C}$ with a flux of about $14 \mathrm{~L} / \mathrm{min}$ and inlet and outlet pressures of around 303.4 and $96.5 \mathrm{kPa}$, respectively.

Each trial employed batch MF and batch UF loops operating in series. The MF permeate containing the WP flowed into the batch UF loop, and the UF permeate flowed into the batch MF loop as a DF fluid. This routine allowed for the small materials in the UF permeate, such as water, vitamins, lactose, and soluble minerals to keep the MF retentate dilute, which only minimally concentrated the milk fat and $\mathrm{CN}$. The UF membranes were used because the smaller pore size allowed for the retention of WP, whereas other smaller molecules may pass through. Diafiltering the MF retentate (milk) with UF permeate also served to keep the MF feed volume and flux rates constant, and therefore to keep WP removal efficient. Diafiltering the MF retentate with UF permeate was continued until most WP depletion was achieved. The total solids (TS) content of each type of permeate was measured via a handheld refractometer to monitor the WP depletion. The filtration process took about $3 \mathrm{~h}$ total.

The control milk consisted of only the whole milk. The 89:100 CN:TP milk was a blend of $\sim 50.5 \pm 8.1 \%$ whole milk, $\sim 42.5 \pm 4.1 \%$ MF retentate, and $\sim 7.0 \pm$ $5.3 \%$ UF permeate. The 95:100 CN:TP milk was a blend of $\sim 83.6 \pm 7.6 \%$ MF retentate and $\sim 16.4 \pm 7.6 \%$ UF permeate. All 3 milks were standardized to approximately 2.3 to $2.4 \% \mathrm{CN}$ and 0.68:1 CN:fat. Standardized milks were pasteurized a second time using the same protocol as mentioned previously.

\section{Cheese Manufacture}

Licensed Wisconsin cheesemakers manufactured 5 batches of milled-curd, full-fat Cheddar cheese at the University of Wisconsin-Madison Dairy Plant over a period of 3 mo. Pasteurized milks were cooled to $32^{\circ} \mathrm{C}$ and inoculated with direct-vat-set mesophilic blended cultures (Danisco MA19, Copenhagen, Denmark) containing Lactococcus lactis ssp. lactis and Lactococcus lactis ssp. cremoris at a rate of $12 \mathrm{~g} / 250 \mathrm{~kg}$ of milk. After $60 \mathrm{~min}$ of ripening, single-strength recombinant calf chymosin (Chy-max Extra, Chr. Hansen, Milwaukee, WI) was added at a rate of $24 \mathrm{~g} / 250 \mathrm{~kg}$ of milk (constant volume of milk). Coagulum was cut at similar firmness, as determined by experienced cheesemakers, with 1.27-cm knives, and then agitated for $20 \mathrm{~min}$. Whey and curd were then heated to $39^{\circ} \mathrm{C}$ over a period of $30 \mathrm{~min}$. Whey was drained when the mixture reached a $\mathrm{pH}$ of approximately 6.35 , and the curd was cut into 6 slabs. Slabs were stacked 2 high and turned every 20 min. When the curd $\mathrm{pH}$ reached 5.4, it was milled and then stirred for $15 \mathrm{~min}$. Curd was then salted at a rate of $770 \mathrm{~g} / 250 \mathrm{~kg}$ of milk. The salted curd was stirred out until a digital moisture analyzer (CEM Corporation, Matthews, NC) determined that the moisture content had reached about $38 \%$. Curd was split into $29-\mathrm{kg}$ Wilson hoops and pressed at $414 \mathrm{kPa}$ for $4 \mathrm{~h}$. Cheese blocks were then removed from the hoops and left overnight at ambient temperature $\left(\sim 25^{\circ} \mathrm{C}\right)$ to simulate the slow cooling regimen used by some in the industry to help with fermentation of residual lactose by the cultures. Cheese blocks were vacuum-packaged and stored at $4^{\circ} \mathrm{C}$ until the following morning.

\section{Compositional Analysis}

All compositional analyses for each sample were carried out in duplicate. Pasteurized whole milk, MF retentate, UF permeate, UF retentate, drain whey, press whey, and standardized milk samples were analyzed for TS content (Green and Park, 1980), total protein (total 
$\%$ of $\mathrm{N} \times 6.35$; Kjeldahl method; AOAC International, 2000), CN (AOAC International, 2000), nonprotein nitrogen (AOAC International, 2000), fat (Mojonnier method; AOAC International, 2000), lactose content (high-performance ion-exchange chromatography; Dionex ICS-5000 RFIC-EGTM Dual System, Thermo Fisher Scientific Inc., Waltham, MA; Møller et al., 2012), and total calcium (inductively coupled argon plasma emission spectroscopy; ICP-OES; Govindasamy-Lucey et al., 2007). The proportion of insoluble calcium (INSOL Ca) of milks was measured by analyzing the calcium content of rennet whey to estimate the content of soluble $\mathrm{Ca}$, by subtracting soluble $\mathrm{Ca}$ from the total Ca content of milk (Hassan et al., 2004).

For cheeses, a slab $2.5 \mathrm{~cm}$ thick was cut off the block, and the outer edges were discarded. This slab was further sampled for each analysis. The composition of ground cheese samples was analyzed at 2 wk for moisture (Marshall, 1992), fat (Mojonnier method; AOAC International, 2000), protein (Kjeldahl method; AOAC International, 2000), salt (chloride electrode method; Johnson and Olson, 1985), and total calcium, sodium, and potassium via ICP-OES (Govindasamy-Lucey et al., 2007). Total coliforms in cheese were also measured at $2 \mathrm{wk}$ using the standard plate count method on petrifilm agar (AOAC International, 2000), and $\mathrm{pH}$ was measured by inserting a spear-tip pH electrode (AB15, Thermo Fisher Scientific) into a cheese block at 1, 14, 30, 90, and $180 \mathrm{~d}$ of ripening. The concentrations of lactose, galactose, and lactic acid in cheese were measured by high-performance ion-exchange chromatography (Møller et al., 2012) at 1, 14, 30, 90, and $180 \mathrm{~d}$ of ripening. Cheese extracts used for chromatographic analyses were prepared according to the method described by Zeppa et al. (2001). The proportion of INSOL Ca in cheese was determined by the acid-base titration method (Hassan et al., 2004) at 1, 14, 30, 90, and $180 \mathrm{~d}$ of ripening.

\section{Mass Balance and Recoveries}

A mass balance was carried out for each vat of cheese according to Govindasamy-Lucey et al. (2006). The starting milk was weighed with a Mars scale (Mars Scale Manufacturing, ISG Series, Ontario, Canada), and the drain and press wheys were weighed on a Rice Lake scale (Rice Lake Weighing Systems, IQ Plus 255, Rice Lake, WI). Cheeses were weighed on a Cream City scale (Cream City Stateline Scale, CW-80, Lake Mills, WI) for each treatment. The percentages of nitrogen, fat, or TS recovered in the cheese, drain whey, and press whey were calculated as the total amount of nitrogen, fat, or TS in each component divided by the total amount of nitrogen, fat, or TS in the original standardized milk multiplied by 100 .
Actual yield was calculated for each vat of cheese as the weight of cheese divided by the weight of the original cheese milk (including the amount of cultures added during cheese manufacture), multiplied by 100 . Yield equations were also calculated for each vat, using the method described by Govindasamy-Lucey et al. (2006). Predictive cheese yields were calculated for each vat using the Van Slyke cheese yield (Equation [1]) as shown (Van Slyke and Price, 1936):

$$
\begin{aligned}
& \text { Van Slyke cheese yield } \\
& =\frac{[(\mathrm{RF} \times \% \text { fat in milk })+(\mathrm{RC} \times \% \text { casein in milk })] \times \mathrm{RS}}{(100-\% \text { moisture in cheese })} \\
& \times 100,
\end{aligned}
$$

where $\mathrm{RF}$ is the fraction of fat recovered in cheese, $\mathrm{RC}$ is the fraction of $\mathrm{CN}$ recovered in cheese, and RS reflects the proportion of other milk solids and salt recovered in cheese in relation to the amount of $\mathrm{CN}$ and fat in cheese.

\section{Nutritional Analysis of Cheeses}

After $1 \mathrm{~d}$ of ripening, cheese samples were sent to Covance Laboratories Inc. (Madison, WI) for nutritional analysis. The total calories were calculated using general conversion factors of 4,4 , and 9 calories per gram of protein, total carbohydrate, and total fat, respectively (Code of Federal Regulations, 2018). Total fat was analyzed by acid hydrolysis (AOAC International, 2005), carbohydrates by the difference method (United States Department of Agriculture, 1973), protein by the Dumas Method (AOAC International, 2005), vitamin A as retinol (AOAC International, 2005), minerals and elements by ICP-AES (calcium, iron, and sodium; AOAC International, 2005), and vitamin C (AOAC International, 2005), ash (AOAC International, 2005), and moisture (AOAC International, 2005) were evaluated for all cheese treatments from the 3 trials. Potassium content in the cheeses was measured for all trials at the Center for Dairy Research, using ICP-OES (Govindasamy-Lucey et al., 2007).

\section{Particle Size Analysis}

The particle size distribution of the whole milk and MF retentate was determined via laser light scattering using a Mastersizer 2000 (Malvern Instruments, Malvern, UK). Samples were diluted in deionized water. Measurements were performed in duplicate at an obscuration value between 12 and 13\%. The particle size distribution was calculated from the light scattering patternw, using Mie theory. A refractive index 
of 1.47 and absorption of 0.01 for milk fat were used. Water was used as the dispersant (refractive index of 1.33; Michalski et al., 2001). Analysis was performed in triplicate.

\section{Rheological Analysis}

Dynamic small-amplitude oscillatory rheology was used to measure the rheological properties of the cheeses. An Anton Paar MCR 301 rheometer (Graz, Austria) with a 50-mm serrated parallel plate geometry was used as described by Lee et al. (2005) and Lucey et al. (2005). Cheese samples $3 \mathrm{~mm}$ in thickness and $50 \mathrm{~mm}$ in diameter were heated from 5 to $85^{\circ} \mathrm{C}$ at the rate of $1^{\circ} \mathrm{C}$ per min. A frequency of $0.08 \mathrm{~Hz}$ and a constant strain of $0.5 \%$ were applied. The storage modulus $\left(\mathrm{G}^{\prime}\right)$, loss modulus $\left(\mathrm{G}^{\prime \prime}\right)$, and loss tangent (LT $\left.=G^{\prime \prime} / G^{\prime}\right)$ were recorded every minute. The $G^{\prime}$ value represents the elastic properties, the $\mathrm{G}^{\prime \prime}$ value represents the viscous properties, and the LT represents the ratio of viscous to elastic moduli. Tests were performed in at least duplicate throughout ripening. Rheological analysis was carried out at ripening times of $2 \mathrm{wk}, 1$, 3, 6 and 9 mo.

\section{Texture Profile Analysis}

Texture profile analysis (TPA) of cheese was measured using a TA.XT2 Texture Analyzer (Texture Technologies Corp., Scarsdale, NY) according to the method of Bourne (1978). Cheese samples were sliced to $17.5 \mathrm{~mm}$ in thickness and cut with a $16-\mathrm{mm}$-diameter cork borer. The test compressed the cheese sample twice by $30 \%$ using a $50-\mathrm{mm}$ aluminum cylinder probe. The probe measured the force required to compress the cheese sample at a constant speed of $0.8 \mathrm{~mm} / \mathrm{s}$. At least 9 replicates per sample were measured at $5^{\circ} \mathrm{C}$. Texture profile analysis was carried out at ripening times of $4 \mathrm{~d}$, 2 wk, and 1, 3, 6, and 9 mo.

\section{Whey Protein Content of Milk and Recovery in Cheese}

The WP contents in milk and cheese were determined using reverse-phase (RP)-HPLC. For identification and quantification of $\alpha-\mathrm{LA}, \beta-\mathrm{LG}$, and BSA in milk and cheese, standard curves were prepared using purified $\alpha$-LA, $\beta$-LG, and BSA from bovine milk (Sigma-Aldrich, St. Louis, MO). Concentrated standard solutions were prepared in solution $\mathrm{A}$, which contained $0.1 M$ BisTris buffer ( $\mathrm{pH} \mathrm{6.8),6} M$ guanidine hydrochloride (GdnHCl), $5.36 \mathrm{mM}$ sodium citrate, and $19.5 \mathrm{~m} M$ DL-dithiothreitol ( $\mathrm{pH}$ 7). The concentrated standard solutions were further diluted at a ratio of $1: 3$ to concentration of $0.1,0.25,0.5,1.0,1.5,2$, and $4 \mathrm{mg} /$ $\mathrm{mL}$ using solution $\mathrm{B}$, which contained $4.5 \mathrm{M} \mathrm{GdnHCl}$ in a solution of acetonitrile, water, and trifluoroacetic acid in a ratio of 100:900:1 (vol:vol:vol, $\mathrm{pH} 2$ ). The diluted standard solutions were then filtered through a $0.22-\mu \mathrm{m}$ syringe filter (Restek, Bellefonte, PA) before RP-HPLC. An injection volume of $25 \mu \mathrm{L}$ was used. Standards were prepared in duplicate. Standard curves were plotted using the concentration of the standard protein and its corresponding peak area.

To prepare rennet whey, rennet (Chymax Extra, double strength, Chr. Hansen) was diluted 10 times using deionized water. We weighed $30 \mathrm{~g}$ of milk into a 50$\mathrm{mL}$ centrifuge tube, and $16.5 \mu \mathrm{L}$ of the diluted rennet was added to the milk and mixed before incubating at $32^{\circ} \mathrm{C}$ for $\sim 1 \mathrm{~h}$ to coagulate. The coagulant was then cut using a spatula and centrifuged at $1,378 \times g$ for $10 \mathrm{~min}$. The supernatant was filtered through Whatman No. 1 filter paper (GE Healthcare UK Ltd., Little Chalfont, UK), and the filtrate was collected. We transferred 500 $\mu \mathrm{L}$ of the filtrate into a $1.5-\mathrm{mL}$ Eppendorf centrifuge tube and stored it at $-20^{\circ} \mathrm{C}$ until analysis. Samples were prepared in triplicate.

Rennet whey samples for RP-HPLC were prepared according to the method of Bobe et al. (1998). First 500 $\mu \mathrm{L}$ of rennet whey was mixed with an equal amount of solution A [0.1 M BisTris buffer (pH 6.8), 6 M GdnHCl, $5.36 \mathrm{~m} M$ sodium citrate, and $19.5 \mathrm{~m} M$ DL-dithiothreitol (pH 7)]. The mixture was then incubated at room temperature for $1 \mathrm{~h}$ before centrifugation at $14,000 \times g$ for $10 \mathrm{~min}$ at $4^{\circ} \mathrm{C}$. The fat layer was removed, and $500 \mu \mathrm{L}$ of the bottom layer was mixed with $1.5 \mathrm{~mL}$ of solution B [4.5 M GdnHCl in a solution of acetonitrile, water, and triflouroacetate acid at a ratio of 100:900:1 (vol: vol:vol, $\mathrm{pH} 2$ )]. The mixture was then filtered through a $0.22-\mu \mathrm{m}$ syringe filter (Restek). Samples were prepared in triplicate. An injection volume of $25 \mu \mathrm{L}$ was used for RP-HPLC. Whey protein content in rennet whey was calculated using the standard curves. Whey protein content in milk was calculated based on the WP content in its rennet whey, and a correction factor was used. The correction factor was calculated based on solids contents in milk and the rennet whey (Davies and White, 1960).

Water-soluble extract (WSE) was prepared from cheeses using the method of Kuchroo and Fox (1982). Young cheese was used to reduce the number of peptide peaks (which could make the identification and analysis of individual WP peaks more difficult) in the chromatogram that would be generated during proteolysis (ripening). After $1 \mathrm{~d}$ of ripening, $20 \mathrm{~g}$ of cheese and $40 \mathrm{~g}$ of deionized water were mixed in a 
stomacher bag and stomached at $260 \mathrm{rpm}$ for $10 \mathrm{~min}$ at room temperature using a Stomacher 400 Circulator (Seward, Islandia, NY). The cheese slurries were then incubated at $40^{\circ} \mathrm{C}$ for $1 \mathrm{~h}$, followed by centrifugation at $3,000 \times g$ for $30 \mathrm{~min}$. The supernatant was filtered through Whatman No. 1 filter paper, and the filtrate was collected as WSE of cheese. We mixed $500 \mu \mathrm{L}$ of the WSE with $500 \mu \mathrm{L}$ of solution A and vortexed for 10 $\mathrm{s}$. This mixture was held at room temperature for $1 \mathrm{~h}$ before centrifuging at $14,000 \times g$ for $10 \mathrm{~min}$ at $4^{\circ} \mathrm{C}$. The fat layer was removed, and $500 \mu \mathrm{L}$ of the bottom layer was mixed with $1.5 \mathrm{~mL}$ of solution $\mathrm{B}$. The mixture was then filtered through a $0.22-\mu \mathrm{m}$ syringe filter (Restek) before RP-HPLC injection. Samples were prepared in triplicate. An injection volume of $100 \mu \mathrm{L}$ was used for RP-HPLC because of the low concentration of WP in cheese. Whey protein content in WSE was calculated using the prepared standard curves $(\alpha-\mathrm{LA}, \beta-\mathrm{LG}$, and BSA). Based on Kuchroo and Fox (1982), the recovery rate of this single-extraction method was $70 \%$, which was used for calculating WP content in cheese.

The determination of WP in milk and cheese via RP-HPLC was based on the method of Bonfatti et al. (2008) with slight modifications. The chromatographic system used to perform the analysis consisted of a Waters Alliance e2695 Separations Module equipped with a Waters 2998 photodiode array detector (Waters, Milford, MA). Separation was performed on a reversedphase analytical column C8 (Zorbax 300SB-C8 RP, 3.5 $\mu \mathrm{m}, 150 \times 4.6$ internal diameter; Agilent Technologies Inc., Santa Clara, CA). Gradient elution was carried out with a mixture of 2 solvents. Solvent A consisted of $0.1 \%$ trifluoroacetic acid in water, and solvent B consisted of $0.1 \%$ trifluoroacetic acid in acetonitrile. Separation were performed using the following program: linear gradient from 25 to $35 \%$ of solvent B in 5 min, from 35 to $37 \%$ solvent B in 4 min, from 37 to $40 \%$ solvent B in $9 \mathrm{~min}$, from 40 to $41 \%$ solvent B in 4 min, followed by an isocratic elution at $41 \%$ solvent B for $5.5 \mathrm{~min}$, then linear gradient elution from 41 to $43 \%$ solvent B in $0.5 \mathrm{~min}$, from 43 to $45 \%$ solvent $\mathrm{B}$ in $8 \mathrm{~min}$, from 45 to $33 \%$ solvent B in $1 \mathrm{~min}$, followed by an isocratic elution at $33 \%$ solvent B for 3 min, then from $33 \%$ to $90 \%$ solvent B in $0.1 \mathrm{~min}$, and return to the starting condition, $25 \% \mathrm{~B}$, in $1.9 \mathrm{~min}$, followed by an isocratic elution at $25 \%$ B for $14 \mathrm{~min}$. The total separation time was $56 \mathrm{~min}$. The flow rate was $0.5 \mathrm{~mL} / \mathrm{min}$, the column temperature was kept at $45^{\circ} \mathrm{C}$, and detection was made at wavelength of $214 \mathrm{~nm}$. Injection volume was $25 \mu \mathrm{L}$ for rennet whey samples and $100 \mu \mathrm{L}$ for WSE of cheese. The percentage of residual WP recovered in the cheese was calculated using the amount found in the initial milks and their respective cheeses, as determined via RP-HPLC analysis.

\section{Proteolysis}

Proteolysis was monitored during ripening by preparing a $\mathrm{pH} 4.6$ soluble extract according to the method reported by Kuchroo and Fox (1982). Total nitrogen in cheese extracts was measured via the Kjeldahl method (AOAC International, 2000) and expressed as a percentage of the total nitrogen in the cheese. These measurements were performed in triplicate at $4 \mathrm{~d}, 2 \mathrm{wk}$, and 1, 3, 6, and 9 mo.

Urea-PAGE was carried out to monitor the breakdown of $\beta$ - and $\alpha_{S_{1}}$ CN. Urea-PAGE gels were prepared according to the method reported by Andrews (1983), as modified by Shalabi and Fox (1987). We dissolved $100 \mathrm{mg}$ of ground cheese in $900 \mu \mathrm{L}$ of sample buffer containing $0.06 \mathrm{M}$ Tris, $8.0 \mathrm{M}$ urea, $5 \%$ (vol/vol) 2-mercaptoethanol, and $0.01 \%$ (wt/vol) bromophenol blue, $\mathrm{pH}$ 7.6. The mixture of cheese sample and buffer was warmed to $55^{\circ} \mathrm{C}$ for $\sim 8 \mathrm{~min}$, until the cheese particles dissolved completely. The dissolved sample was diluted 10 times using sample buffer and mixed thoroughly before loading to the gel. A standard dual-cooled vertical slab gel electrophoresis unit SE 600 (Hoefer Scientific Instruments, San Francisco, CA) was used for electrophoresis. Separating gel (10\% acrylamide) was prepared by dissolving $0.20 \mathrm{~g}$ of $\mathrm{N}, \mathrm{N}$-methylene bisacrylamide in a mixture of $10 \mathrm{~mL}$ of $40 \%$ acrylamide solution and $30 \mathrm{~mL}$ of Tris-HCl buffer containing 0.33 $M$ Tris and 4.33 $M$ urea, $\mathrm{pH}$ 8.9. TEMED (N,N,N, $\mathrm{N}^{\prime}-$ tetramethylethane-1,2-diamine; $20 \mu \mathrm{L})$ and $10 \%$ ammonium persulphate solution $(150 \mu \mathrm{L})$ were added to the separating gel solution before gel casting to catalyze polymerization. Stacking gel was prepared by dissolving $0.028 \mathrm{~g}$ of $\mathrm{N}, \mathrm{N}$-methylene bisacrylamide in a mixture of $1.38 \mathrm{~mL}$ of $40 \%$ acrylamide solution and $12.5 \mathrm{~mL}$ of Tris- $\mathrm{HCl}$ buffer containing $0.06 M$ Tris and $4.33 M$ urea, $\mathrm{pH}$ 7.6. Then TEMED $(6.9 \mu \mathrm{L})$ and $10 \%$ ammonium persulphate solution $(83 \mu \mathrm{L})$ were added into the separating gel solution before gel casting to catalyze polymerization. Twenty micrograms of protein of each cheese sample $(7-9 \mu \mathrm{L}$ of the $10 \times$ diluted sample solution, based on the protein content in cheese) was loaded onto the gel, and electrophoresis was performed in electrode buffer containing $0.025 \mathrm{M}$ Tris and $0.19 \mathrm{M}$ glycine. Electrophoresis was carried out at a constant voltage of $300 \mathrm{~V}$ for $\sim 3.5 \mathrm{~h}$. During electrophoresis, water at $\sim 22^{\circ} \mathrm{C}$ was circulated to remove the heat generated by electrophoresis. Gel was simultaneously fixed and stained with $0.04 \%$ Coomassie brilliant blue R-250 staining solution (Bio-Safe Coomassie Premixed Staining Solution, Bio-Rad, Hercules, CA) for $\sim 1 \mathrm{~h}$ before destaining with distilled water. Gels were photographed and analyzed using densitometric analysis software (Gel Analyzer 2010a, developed by Istvan Lazar; http: 
//www.gelanalyzer.com/). Urea-PAGE was performed in duplicate.

\section{Sensory Analysis}

Quantitative descriptive analyses of cheese texture and flavors were evaluated by sensory panelists $(\mathrm{n} \leq$ 9) who had at least $40 \mathrm{~h}$ of training according to the method by Meilgaard et al. (1999). The cheese was evaluated in the form of uniform cubes at $11^{\circ} \mathrm{C}$ for the following attributes: firmness, cohesiveness, chewiness, adhesiveness, sweetness, saltiness, bitterness, acidity, milkfat, butteriness, brothiness, sourness, sulfur, rancidity, cardboard, burn, and astringency. Firmness is the amount of force required to compress the sample between thumb and forefinger by about 30\%. Cohesiveness is the degree to which a sample chewed 5 to 7 times holds together on the palette. Chewiness is the amount of total energy required to masticate the sample to a state ready for swallowing. Adhesiveness is the degree to which a mass chewed 12 to 15 times sticks to the teeth and palette surface. Basic tastes (sweet, salty, bitter, and acid) were evaluated as compared with references of water mixed with varying amounts of sugar, salt, caffeine, and lactic acid, respectively. All flavor attributes were scored on a 15 -point scale, 0 being absence of the flavor and 15 being overwhelming presence of the flavor. These analyses were performed at 3,6 , and 9 mo for each cheese.

\section{Experimental Design and Statistical Analysis}

Five replicate cheesemaking trials were carried out over a period of $3 \mathrm{mo}$. In each trial, 3 standardized milks (83:100 CN:TP or control, 89:100 CN:TP, and 95:100 CN:TP) were used to make Cheddar cheese. A $3 \times 5$ completely randomized block design, which incorporated all 3 treatments and all 5 replicate trials, was used for analysis of the response variables related to milk, cheese, and whey composition. Using SAS version 9.4 (SAS Institute Inc., Cary, NC) ANOVA was performed. The 3 different standardized milks (treatments) were analyzed as discontinuous variables where the 5 cheesemaking trials were blocked. Duncan's multiple-comparison test was carried out to evaluate differences in treatment means. A significance level of $P<0.05$ was used.

A split-plot design was used to monitor the effects of both treatment and ripening time and their interactions on $\mathrm{pH}, \mathrm{LT}_{\max }, \mathrm{LT}_{\max }$ temperature, crossover point temperature, hardness, proteolysis, INSOL Ca, urea-PAGE, and sensory attributes during ripening. For the whole-plot factor, the treatment was analyzed as a discontinuous variable, and the cheesemaking trial was blocked. For the subplot factor analysis, age was treated as a continuous variable. The interactive term treatment $\times$ cheesemaking trial was treated as the error term for treatment effect. Analysis of variance for the split-plot design was carried out using SAS. Duncan's multiple-comparisons test was carried out to evaluate differences in the treatment means at each ripening time at a significance level of $P<0.05$.

\section{RESULTS AND DISCUSSION}

\section{Composition of Fluids}

The chemical compositions of whole milk, MF retentate, UF retentate, and UF permeate can be found in Table 1 . The UF permeate had only about $0.17 \%$ total protein, which was likely mostly nonprotein nitrogen rather than actual protein. This showed that almost all of the proteins from the starting whole milk $(3.02 \%)$ were retained by either MF (mostly CN) or UF (mostly WP). Furthermore, the UF retentate contained $0.11 \%$ $\mathrm{CN}$, which demonstrated that the MF retained most of the $\mathrm{CN}$ but allowed some soluble $\mathrm{CN}$ to permeate. The $\mathrm{CN}$ found in the UF retentate was most likely soluble $\mathrm{CN}$ rather than micellar CN. Particle size analysis indicated that whole milk had smaller particle size $(P<$ 0.05) compared with the MF retentate. The volume mean diameter $(\mathrm{D}[4,3])$ values were 3.81 and $3.33 \mu \mathrm{m}$ in whole milk and MF retentate, respectively. These results indicated that the MF process did not homogenize fat globules due to processing operations such as pumping and filtration. This is in agreement with the results of Michalski et al. (2006) who found a larger milk fat globule retained in MF retentate compared with that in whole milk. Because the MF setup used in the present study did not homogenize the milk fat globule, the MF retentate displayed an increase in the milk fat globule $\mathrm{D}[4,3]$ values, likely due to the loss of small fat globules $(<0.1 \mu \mathrm{m})$ into the MF permeate.

\section{Composition of Standardized Cheese Milks}

The compositional analysis of the standardized milks is shown in Table 2. Some small differences in fat and CN contents were detectable between the milk treatments, which could have affected cheese yields. The TS content slightly decreased with increasing WP depletion. The WP contributed to the solids content in the control milk $(0.56 \%)$, and WP were highly depleted $(0.16 \%)$ in the 95:100 CN:TP milk. The total protein and TP content decreased with MF treatment (Table 2). This was because the WP were increasingly depleted with MF. The MF processing successfully removed around $75 \%$ of the original WP from the starting milk. The CN:total 
protein and $\mathrm{CN}$ :TP subsequently increased with MF treatment because of the decrease in WP.

\section{Composition of Cheeses}

The composition of each type of cheese is shown in Table 2. The moisture, protein, and moisture in the nonfat substance content of cheese did not significantly differ between the 3 cheese treatments. The residual WP content in the cheeses made from MF milk were lower than the control (Table 2) due to the depletion of WP during MF processing. The total protein contents of the various cheese milks were different; however, the total protein contents in the cheeses were similar between treatments (Table 2). This was because the starting milk had been standardized to a similar casein content $(\sim 2.4 \%)$ as well as to the same casein:fat ratio (Table 2). Although the WP content of milks decreased with MF treatment (Table 2), the WP are mostly lost in the whey and therefore do not usually contribute much to the total protein content of cheese. The WP contents in cheeses were $0.11,0.06$, and $0.03 \%$ in the control, 89:100 CN:TP, and 95:100 CN:TP treatments, respectively (Table 2). Lelievre and Lawrence (1988) estimated (calculation) around $0.3 \%$ residual WP in Cheddar cheese, which was higher than the levels we determined in the control cheese. We used RP-HPLC to determine the WP of cheese, and we were not able to measure the very low levels of minor proteins such as lactoferrin in cheese. The WP contribution to the total protein in cheese was $0.4,0.2$, and $0.1 \%$ in the control, 89:100 CN:TP, and 95:100 CN:TP treatments, respectively.

The contents of fat and fat in the DM slightly increased with MF treatment (Table 2). This can be attributed to the MF-treated cheese milks having been standardized to a slightly higher fat content (Table 2).
The salt content also slightly decreased with MF treatment. The calcium and potassium levels were similar in all cheeses (Table 2).

Detailed results for $\mathrm{pH}$ and lactic acid contents for the cheeses during ripening are shown in Table 3. The $\mathrm{pH}$ values were not significantly affected by treatment or ripening time (Table 4). The $\mathrm{pH}$ values for all treatments and time points ranged between 5.20 and 5.27. We detected a small increase in lactic acid levels during ripening for all cheeses (Table 3). Residual lactose was slowly fermented in the control cheese, possibly due to its higher salt-in-moisture level (Table 2). Treatment did not significantly influence lactose or lactic acid levels (Table 4). Variations in $\mathrm{pH}$ during ripening could be due to fermentation of residual lactose into lactic acid, thus decreasing the $\mathrm{pH}$, or to solubilization of INSOL Ca phosphate releasing phosphate ions, which bind $\mathrm{H}^{+}$ ions, resulting in buffering that can cause an increase in $\mathrm{pH}$ (Hassan et al., 2004). These 2 opposing trends tend to reduce the likelihood of large $\mathrm{pH}$ changes in many Cheddar cheeses.

\section{Composition of Cheese Whey}

The composition of each cheese whey is shown in Table 2. The TS and protein content in drain whey decreased with treatment, because WP were depleted from the cheese milks via MF. The fat content in the drain whey very slightly (but not significantly) increased with treatment, possibly because slightly more fat was present in the MF milks. This trend was in agreement with the findings of Guinee et al. (2007), who also observed an increased fat content in drain whey when milks with a higher fat content were used for Cheddar cheese manufacture. Minor differences were detectable in the composition of press wheys, apart from lower protein levels in the MF-treated samples.

Table 1. Average composition of pasteurized whole milk, microfiltration (MF) retentate, ultrafiltration (UF) retentate, and UF permeate ${ }^{1}$

\begin{tabular}{|c|c|c|c|c|}
\hline Item & Whole milk & MF retentate & UF retentate & UF permeate \\
\hline Solids (\%) & $11.95 \pm 0.17$ & $12.87 \pm 0.72$ & $7.14 \pm 0.21$ & $5.24 \pm 0.29$ \\
\hline Fat (\%) & $3.44 \pm 0.05$ & $4.44 \pm 0.40$ & $\mathrm{ND}^{2}$ & ND \\
\hline Total protein ${ }^{3}(\%)$ & $3.17 \pm 0.09$ & $3.41 \pm 0.28$ & $1.52 \pm 0.18$ & $0.17 \pm 0.01$ \\
\hline True protein ${ }^{4}(\%)$ & $3.02 \pm 0.08$ & $3.23 \pm 0.28$ & $1.33 \pm 0.18$ & ND \\
\hline Casein $^{5}(\%)$ & $2.47 \pm 0.06$ & $3.08 \pm 0.27$ & $0.11 \pm 0.05$ & ND \\
\hline Casein:total protein (\%) & $77.97 \pm 0.37$ & $90.35 \pm 0.75$ & $6.97 \pm 2.45$ & ND \\
\hline Casein:true protein (\%) & $81.80 \pm 1.35$ & $95.48 \pm 0.36$ & $8.01 \pm 2.69$ & ND \\
\hline Casein:fat & $0.72 \pm 0.02$ & $0.70 \pm 0.01$ & ND & ND \\
\hline
\end{tabular}

${ }^{1}$ Values represent the means and SD of 5 replicates for each treatment.

${ }^{2} \mathrm{ND}=$ not determined.

${ }^{3}$ Total $\% \mathrm{~N} \times 6.35$.

${ }^{4}($ Total \% N $-\%$ nonprotein N) $\times 6.35$.

${ }^{5}($ Total $\% \mathrm{~N}-\%$ noncasein $\mathrm{N}) \times 6.36$. 


\section{Mass, Nitrogen, Fat, Solids, and WP Recoveries}

The recoveries of mass and milk components are shown in Table 5. We detected a significant increase in cheese mass with increasing WP depletion. Small increases were also detectable in actual cheese yield and
Van Slyke cheese yield in the 95:100 CN:TP sample compared with the control (Table 6). The increase in cheese mass recovery was due to a significant increase in nitrogen and solids recovery in the MF cheeses (Table 5). The slightly higher (not significant) fat and casein levels in the 95:100 CN:TP milk compared with the

Table 2. Compositions of standardized cheese milks that had various levels of whey protein depletion, and the derived drain whey, press whey, and Cheddar cheese ${ }^{1}$

\begin{tabular}{|c|c|c|c|c|c|}
\hline \multirow[b]{2}{*}{ Component } & \multicolumn{3}{|c|}{ Treatment $^{2}$} & \multirow[b]{2}{*}{ SEM } & \multirow[b]{2}{*}{$P$-value ${ }^{3}$} \\
\hline & Control & 89:100 CN:TP & 95:100 CN:TP & & \\
\hline \multicolumn{6}{|l|}{ Standardized cheese milk } \\
\hline Lactose $(\%)$ & $4.26^{\mathrm{a}}$ & $4.36^{\mathrm{a}}$ & $4.23^{\mathrm{a}}$ & 0.07 & $<0.05$ \\
\hline Solids $(\%)$ & $11.56^{\mathrm{a}}$ & $11.56^{\mathrm{a}}$ & $11.25^{\mathrm{b}}$ & 0.03 & $<0.05$ \\
\hline Fat $(\%)$ & $3.24^{\mathrm{b}}$ & $3.40^{\mathrm{a}}$ & $3.49^{\mathrm{a}}$ & 0.02 & $<0.01$ \\
\hline Total protein ${ }^{4}(\%)$ & $2.98^{\mathrm{a}}$ & $2.90^{\mathrm{a}}$ & $2.71^{\mathrm{b}}$ & 0.02 & $<0.01$ \\
\hline True protein 5 (\%) & $2.80^{\mathrm{a}}$ & $2.73^{\mathrm{a}}$ & $2.54^{\mathrm{b}}$ & 0.02 & $<0.01$ \\
\hline Casein $^{6}(\%)$ & $2.34^{\mathrm{a}}$ & $2.43^{\mathrm{a}}$ & $2.42^{\mathrm{a}}$ & 0.30 & 0.05 \\
\hline Casein:total protein (\%) & $78.58^{\mathrm{c}}$ & $83.91^{\mathrm{b}}$ & $89.22^{\mathrm{a}}$ & 0.39 & $<0.01$ \\
\hline Casein:true protein $(\%)$ & $83.64^{\mathrm{c}}$ & $89.08^{\mathrm{b}}$ & $95.28^{\mathrm{a}}$ & 0.004 & $<0.01$ \\
\hline Casein:fat & $0.72^{\mathrm{a}}$ & $0.71^{\mathrm{a}}$ & $0.69^{\mathrm{b}}$ & 0.02 & $<0.01$ \\
\hline Whey protein ${ }^{7}(\%)$ & $0.56^{\mathrm{a}}$ & $0.37^{\mathrm{b}}$ & $0.18^{\mathrm{c}}$ & 0.05 & $<0.01$ \\
\hline Total calcium ${ }^{8}$ (mg/100 g of milk) & $113^{\mathrm{a}}$ & $115^{\mathrm{a}}$ & $115^{\mathrm{a}}$ & 1.01 & 0.08 \\
\hline Insoluble calcium (mg/100 g of milk) & $73^{\mathrm{a}}$ & $75^{\mathrm{a}}$ & $77^{\mathrm{a}}$ & 1.61 & NS \\
\hline Calcium (mg/g of protein) & $37.86^{\mathrm{c}}$ & $39.66^{\mathrm{b}}$ & $42.55^{\mathrm{a}}$ & 0.23 & $<0.01$ \\
\hline Calcium (mg/g of casein) & $48.49^{\mathrm{a}}$ & $47.28^{\mathrm{a}}$ & $47.69^{\mathrm{a}}$ & 0.23 & $<0.05$ \\
\hline Insoluble calcium (mg/g of protein) & $24.52^{\mathrm{b}}$ & $26.41^{\mathrm{a}}$ & $27.56^{\mathrm{a}}$ & 0.56 & $<0.05$ \\
\hline Insoluble calcium (mg/g of casein) & $31.20^{\mathrm{a}}$ & $31.48^{\mathrm{a}}$ & $30.88^{\mathrm{a}}$ & 0.68 & NS \\
\hline \multicolumn{6}{|l|}{ Drain whey } \\
\hline Solids (\%) & $6.56^{\mathrm{a}}$ & $6.23^{\mathrm{b}}$ & $5.89^{\mathrm{c}}$ & 0.03 & $<0.01$ \\
\hline Fat (\%) & $0.35^{\mathrm{a}}$ & $0.36^{\mathrm{a}}$ & $0.37^{\mathrm{a}}$ & 0.01 & $<0.01$ \\
\hline Total protein $(\%)$ & $0.83^{\mathrm{a}}$ & $0.65^{\mathrm{b}}$ & $0.44^{\mathrm{c}}$ & 0.01 & $<0.01$ \\
\hline True protein $(\%)$ & $0.58^{\mathrm{a}}$ & $0.41^{\mathrm{b}}$ & $0.20^{\mathrm{c}}$ & 0.01 & $<0.01$ \\
\hline Whey protein $(\%)$ & $0.54^{\mathrm{a}}$ & $0.37^{\mathrm{b}}$ & $0.17^{\mathrm{c}}$ & 0.79 & $<0.01$ \\
\hline \multicolumn{6}{|l|}{ Press whey } \\
\hline Solids (\%) & $17.98^{\mathrm{a}}$ & $16.91^{\mathrm{a}}$ & $18.45^{\mathrm{a}}$ & 0.27 & 0.05 \\
\hline Fat $(\%)$ & $2.62^{\mathrm{a}}$ & $2.34^{\mathrm{a}}$ & $2.85^{\mathrm{a}}$ & 0.27 & 0.26 \\
\hline Total protein (\%) & $1.13^{\mathrm{a}}$ & $0.88^{\mathrm{b}}$ & $0.72^{\mathrm{c}}$ & 0.02 & $<0.01$ \\
\hline True protein $(\%)$ & $0.80^{\mathrm{a}}$ & $0.58^{\mathrm{b}}$ & $0.43^{\mathrm{c}}$ & 0.01 & $<0.01$ \\
\hline \multicolumn{6}{|l|}{ Cheese (at $14 \mathrm{~d}$ ) } \\
\hline Moisture (\%) & $36.27^{\mathrm{a}}$ & $35.99^{\mathrm{a}}$ & $36.03^{\mathrm{a}}$ & 0.23 & NS \\
\hline Fat $(\%)$ & $32.75^{\mathrm{b}}$ & $33.13^{\mathrm{ba}}$ & $33.52^{\mathrm{a}}$ & 0.11 & $<0.01$ \\
\hline Salt (\%) & $1.87^{\mathrm{a}}$ & $1.75^{\mathrm{ba}}$ & $1.59^{\mathrm{b}}$ & 0.05 & $<0.05$ \\
\hline Potassium $^{8}$ (mg/100 g of cheese) & $101^{\mathrm{a}}$ & $99^{\mathrm{a}}$ & $99^{\mathrm{a}}$ & 1.68 & NS \\
\hline Calcium (mg/100 g of cheese) & $776^{\mathrm{a}}$ & $770^{\mathrm{a}}$ & $774^{\mathrm{a}}$ & 10.1 & NS \\
\hline Protein $^{9}(\%)$ & $25.39^{\mathrm{a}}$ & $25.29^{\mathrm{a}}$ & $25.37^{\mathrm{a}}$ & 0.09 & NS \\
\hline Moisture in nonfat substance (\%) & $53.93^{\mathrm{a}}$ & $53.81^{\mathrm{a}}$ & $54.20^{\mathrm{a}}$ & 0.32 & NS \\
\hline Fat in DM (\%, dry weight basis) & $51.39^{\mathrm{b}}$ & $51.75^{\mathrm{ba}}$ & $52.40^{\mathrm{a}}$ & 0.19 & $<0.05$ \\
\hline Salt in moisture phase $(\%)$ & $5.17^{\mathrm{a}}$ & $4.87^{\text {ba }}$ & $4.42^{\mathrm{b}}$ & 0.14 & $<0.05$ \\
\hline Whey protein $(\%)$ & $0.10^{\mathrm{a}}$ & $0.06^{\mathrm{b}}$ & $0.02^{\mathrm{c}}$ & 0.01 & $<0.01$ \\
\hline
\end{tabular}

${ }^{\mathrm{a}-\mathrm{c}}$ Means within the same row not sharing a common superscript differ $(P<0.05)$.

${ }^{1}$ Values represent the means of 5 replicates for each treatment.

${ }^{2}$ The means of the 3 main treatments [different ratios of casein to true protein (TP): control, 89:100 CN:TP, 95:100 CN:TP] were analyzed using ANOVA of PROC GLM in SAS (version 9.1; SAS Institute Inc., Cary, NC). Duncan's multiple-comparison test was used to evaluate differences in the treatments at a significance level of $P<0.05$.

${ }^{3}$ Value for full statistical model that incorporated all 3 treatments and 5 blocks ( 5 replicate cheesemaking days).

${ }^{4}$ Total $\% \mathrm{~N} \times 6.35$.

${ }^{5}($ Total $\% \mathrm{~N}-\%$ nonprotein $\mathrm{N}) \times 6.35$.

${ }^{6}($ Total $\% \mathrm{~N}-\%$ noncasein $\mathrm{N}) \times 6.36$.

${ }^{7}$ Measured by reverse-phase HPLC.

${ }^{8}$ Measured by inductively coupled argon plasma emission spectroscopy.

${ }^{9}$ Total $\% \mathrm{~N} \times 6.31$. 
Table 3. $\mathrm{pH}$ values, lactose (\%), and lactic acid contents (\%) of Cheddar cheeses that had various levels of whey protein depletion during ripening ${ }^{1}$

\begin{tabular}{lcccc}
\hline & & \multicolumn{3}{c}{ Treatment $^{2}$} \\
\cline { 3 - 5 } Item & $\begin{array}{c}\text { Ripening } \\
\text { time (d) }\end{array}$ & Control & $89: 100$ CN:TP & $95: 100$ CN:TP \\
\hline $\mathrm{pH}$ & 4 & $5.23^{\mathrm{a}}$ & $5.26^{\mathrm{a}}$ & $5.21^{\mathrm{a}}$ \\
& 14 & $5.27^{\mathrm{a}}$ & $5.23^{\mathrm{a}}$ & $5.24^{\mathrm{a}}$ \\
& 30 & $5.26^{\mathrm{a}}$ & $5.21^{\mathrm{a}}$ & $5.26^{\mathrm{a}}$ \\
& 90 & $5.24^{\mathrm{a}}$ & $5.23^{\mathrm{a}}$ & $5.24^{\mathrm{a}}$ \\
& 180 & $5.21^{\mathrm{a}}$ & $5.20^{\mathrm{a}}$ & $5.28^{\mathrm{a}}$ \\
& 270 & $5.20^{\mathrm{a}}$ & $5.22^{\mathrm{a}}$ & $5.24^{\mathrm{a}}$ \\
& 4 & $0.40^{\mathrm{a}}$ & $0.31^{\mathrm{a}}$ & $0.26^{\mathrm{a}}$ \\
& 14 & $0.38^{\mathrm{a}}$ & $0.23^{\mathrm{a}}$ & $0.12^{\mathrm{a}}$ \\
& 30 & $0.32^{\mathrm{a}}$ & $0.16^{\mathrm{a}}$ & $0.11^{\mathrm{a}}$ \\
& 90 & $0.23^{\mathrm{a}}$ & $0.11^{\mathrm{a}}$ & $0.05^{\mathrm{a}}$ \\
& 180 & $0.19^{\mathrm{a}}$ & $0.09^{\mathrm{a}}$ & $0.04^{\mathrm{a}}$ \\
& 270 & $0.15^{\mathrm{a}}$ & $0.08^{\mathrm{a}}$ & $0.05^{\mathrm{a}}$ \\
& 4 & $0.85^{\mathrm{a}}$ & $0.92^{\mathrm{a}}$ & $0.88^{\mathrm{a}}$ \\
& 14 & $0.92^{\mathrm{a}}$ & $0.97^{\mathrm{a}}$ & $1.02^{\mathrm{a}}$ \\
& 30 & $0.99^{\mathrm{a}}$ & $1.10^{\mathrm{a}}$ & $1.11^{\mathrm{a}}$ \\
& 90 & $1.08^{\mathrm{a}}$ & $1.15^{\mathrm{a}}$ & $1.17^{\mathrm{a}}$ \\
& 180 & $1.18^{\mathrm{a}}$ & $1.23^{\mathrm{a}}$ & $1.23^{\mathrm{a}}$ \\
& 270 & $1.27^{\mathrm{a}}$ & $1.29^{\mathrm{a}}$ & $1.27^{\mathrm{a}}$ \\
& & &
\end{tabular}

${ }^{\mathrm{a}}$ Means within the same row not sharing a common superscript differ $(P<0.05)$.

${ }^{1}$ Values represent the means of 5 replicates for each treatment.

${ }^{2}$ Treatments represent different ratios of casein to true protein (TP).

control probably contributed to the small increase in cheese yield observed for the MF treatment (because the fat and $\mathrm{CN}$ recoveries were similar in all treatments; Table 6).

Nitrogen recovery in cheese increased with WP depletion (Table 5). This was in agreement with results reported by Govindasamy-Lucey et al. (2007), Neocleous et al. (2002a), and Nelson and Barbano (2005b). Nitrogen in bovine milk occurs in the form of CN, WP, and nonprotein nitrogen such as urea, amino acids, and creatine. The amount of WP in milk decreased with MF (Table 2), which resulted in a lower proportion of WP in the nitrogen fraction for the 89:100 CN:TP and 95:100 CN:TP cheese milks compared with the control milk. Caseins are effectively recovered in cheesemaking, so increasing the proportion of $\mathrm{CN}$ in cheese milk results in a more efficient cheesemaking process, in terms of protein recovery. This likely explained why nitrogen recovery in the $95: 100 \mathrm{CN}$ :TP cheese was the highest, because it contained highest proportion of CN as a function of the nitrogen in the milk. The same explanation may apply to the higher TS recovery in the MF cheeses (Table 5). Because the 89:100 CN:TP and 95:100 CN:TP milks had less WP contributing to their starting TS content, they lost fewer solids to the whey, thus increasing the effective solids recovery in the cheese.

Fat recovery in cheese was not affected by treatment (Table 5). Previous studies (Govindasamy-Lucey et al., 2007; Brandsma and Rizvi, 2001) have reported increases in fat recovery in cheese made from MF concentrated milk. However, the milks in the present study were not concentrated and were manufactured by identical cheesemaking processes, so the similar fat recovery between treatments was expected. Homogenization of milk fat globules can lead to the adsorption of $\mathrm{CN}$ and WP onto the fat surface and, thus, greater retention in the cheese protein matrix. However, our MF process had no homogenization effect (i.e., no significant change in the fat particle size).

The non-CN, nonfat solids recovery was also lower in the 95:100 CN:TP cheese (Table 6), possibly due to poorer salt recovery. Levels of WP recovery in the control, 89:100 CN:TP, and 95:100 CN:TP cheeses were $1.56,1.55$, and $1.12 \%$, respectively. The WP recovery was significantly lower in the 95:100 CN:TP cheeses.

Table 4. Degrees of freedom, statistical significance ( $P$-values), and $\mathrm{R}^{2}$ values for changes in $\mathrm{pH}$, lactose, lactic acid, hardness, insoluble calcium content, and proteolysis ( $\mathrm{pH}$ 4.6-soluble nitrogen, expressed as a percentage of total nitrogen) for Cheddar cheeses that had various levels of whey protein depletion during ripening

\begin{tabular}{|c|c|c|c|c|c|c|c|}
\hline Factor $^{1}$ & df & $\mathrm{pH}$ & Lactose & Lactic acid & TPA hardness ${ }^{2}$ & Insoluble $\mathrm{Ca}^{3}$ & Proteolysis ${ }^{4}$ \\
\hline Treatment $(\mathrm{T})$ & 2 & 0.46 & 0.12 & 0.08 & 0.43 & 0.34 & 0.79 \\
\hline Day of cheesemaking (D) & 4 & 0.12 & $<0.01$ & $<0.01$ & 0.03 & 0.03 & 0.99 \\
\hline \multicolumn{8}{|l|}{ Split-plot } \\
\hline Age (A) & 5 & 0.80 & $<0.01$ & $<0.01$ & $<0.01$ & $<0.01$ & $<0.01$ \\
\hline $\mathrm{A} \times \mathrm{T}$ & 10 & 0.33 & 0.26 & 0.90 & 0.52 & 0.64 & 0.98 \\
\hline
\end{tabular}

${ }^{1}$ Split-plot design with the 3 treatments [different ratios of casein to true protein (TP): control, 89:100 CN:TP, 95:100 CN:TP] analyzed as a discontinuous variable and cheesemaking day blocked $(3 \times 5)$. Subplot included the effect of age of cheese $(\mathrm{A})$ and age $\times$ treatment as variables.

${ }^{2}$ Texture profile analysis (TPA) hardness was measured by texture analyzer.

${ }^{3}$ Percentage of insoluble calcium as a percentage of total calcium.

${ }^{4} \mathrm{pH} 4.6$-soluble nitrogen as a percentage of total nitrogen. 
Table 5. Fat, nitrogen, and solids recoveries in the Cheddar cheeses manufactured from milks that had various levels of whey protein depletion ${ }^{1}$

\begin{tabular}{|c|c|c|c|c|c|}
\hline \multirow[b]{2}{*}{ Component recovery } & \multicolumn{3}{|c|}{ Treatment $^{2}$} & \multirow[b]{2}{*}{ SEM } & \multirow[b]{2}{*}{$P$-value ${ }^{3}$} \\
\hline & Control & 89:100 CN:TP & 95:100 CN:TP & & \\
\hline \multicolumn{6}{|l|}{ Fat recovery $(\%)$} \\
\hline Cheese & $87.95^{\mathrm{a}}$ & $88.34^{\mathrm{a}}$ & $87.30^{\mathrm{a}}$ & 0.87 & 0.26 \\
\hline Drain whey & $11.45^{\mathrm{a}}$ & $11.42^{\mathrm{a}}$ & $11.09^{\mathrm{a}}$ & 0.49 & 0.17 \\
\hline Press whey & $1.19^{\mathrm{a}}$ & $1.06^{\mathrm{a}}$ & $1.17^{\mathrm{a}}$ & 0.14 & 0.48 \\
\hline Total & 100.59 & 100.82 & 99.56 & & \\
\hline \multicolumn{6}{|l|}{ Nitrogen recovery (\%) } \\
\hline Cheese & $74.79^{\mathrm{c}}$ & $79.64^{\mathrm{b}}$ & $85.57^{\mathrm{a}}$ & 0.75 & $<0.01$ \\
\hline Drain whey & $25.67^{\mathrm{a}}$ & $20.32^{\mathrm{b}}$ & $14.48^{\mathrm{c}}$ & 0.35 & $<0.01$ \\
\hline Press whey & $0.62^{\mathrm{a}}$ & $0.57^{\text {ba }}$ & $0.38^{\mathrm{b}}$ & 0.05 & $<0.05$ \\
\hline Total & 101.08 & 100.53 & 100.43 & & \\
\hline \multicolumn{6}{|l|}{ Solid recovery (\%) } \\
\hline Cheese & $47.97^{\mathrm{b}}$ & $50.18^{\mathrm{a}}$ & $51.57^{\mathrm{a}}$ & 0.42 & $<0.01$ \\
\hline Drain whey & $51.40^{\mathrm{a}}$ & $48.66^{\mathrm{b}}$ & $47.21^{\mathrm{c}}$ & 0.24 & $<0.01$ \\
\hline Press whey & $2.29^{\mathrm{a}}$ & $2.23^{\mathrm{a}}$ & $2.31^{\mathrm{a}}$ & 0.05 & 0.08 \\
\hline Total & 101.66 & 101.07 & 101.09 & & \\
\hline Drain whey ${ }^{4}(\%$, mass $)$ & $89.42^{\mathrm{a}}$ & $89.26^{\mathrm{a}}$ & $89.15^{\mathrm{a}}$ & 0.11 & 0.16 \\
\hline Press whey ${ }^{4}(\%$, mass $)$ & $1.48^{\mathrm{a}}$ & $1.53^{\mathrm{a}}$ & $1.41^{\mathrm{a}}$ & 0.05 & 0.36 \\
\hline
\end{tabular}

${ }^{\mathrm{a} c}$ Means within the same row not sharing a common superscript differ $(P<0.05)$.

${ }^{1}$ Values represent the means of 5 replicates for each treatment.

${ }^{2}$ The means of the 3 main treatments [different ratios of casein to true protein (TP): control, 89:100 CN:TP, 95:100 CN:TP] were analyzed using ANOVA of PROC GLM in SAS (version 9.1; SAS Institute Inc., Cary, NC). Duncan's multiple-comparison test was used to evaluate differences in the treatments at a significance level of $P<0.05$.

${ }^{3}$ Value for full statistical model that incorporated all 3 treatments and 5 blocks ( 5 replicate cheesemaking days).

${ }^{4}$ Amount of drain whey and press whey obtained from $100 \mathrm{~kg}$ of cheese milk.

Table 6. Actual and calculated cheese yield values for Cheddar cheeses that had various levels of whey protein depletion $^{1}$

\begin{tabular}{|c|c|c|c|c|c|}
\hline \multirow[b]{2}{*}{ Item } & \multicolumn{3}{|c|}{ Treatment $^{2}$} & \multirow[b]{2}{*}{ SEM } & \multirow[b]{2}{*}{$P$-value ${ }^{3}$} \\
\hline & Control & 89:100 CN:TP & 95:100 CN:TP & & \\
\hline$\overline{R F}$ value ${ }^{4}$ & 0.880 & 0.881 & 0.873 & $\mathrm{ND}^{5}$ & ND \\
\hline RC value ${ }^{6}$ & 0.950 & 0.950 & 0.950 & ND & ND \\
\hline RS value ${ }^{7}$ & 1.093 & 1.092 & 1.086 & ND & ND \\
\hline Actual vield ${ }^{8}(\%)$ & $8.71^{\mathrm{b}}$ & $9.06^{\mathrm{ba}}$ & $9.07^{\mathrm{a}}$ & 0.10 & 0.05 \\
\hline $\begin{array}{l}\text { Van Slyke cheese yield }{ }^{9}(\%) \text { using } \\
\text { RF, RC, and RS values }\end{array}$ & $8.70^{\mathrm{b}}$ & $9.03^{\text {ba }}$ & $9.07^{\mathrm{a}}$ & 0.01 & 0.05 \\
\hline
\end{tabular}

$\overline{\mathrm{a}, \mathrm{b}}$ Means within the same row not sharing a common superscript differ $(P<0.05)$.

${ }^{1}$ Values represent the means of 5 replicates for each treatment.

${ }^{2}$ The means of the 3 main treatments [different ratios of casein to true protein (TP): control, 89:100 CN:TP, 95:100 CN:TP] were analyzed using ANOVA of PROC GLM in SAS (version 9.1; SAS Institute Inc., Cary, NC). Duncan's multiple-comparison test was used to evaluate differences in the treatments at a significance level of $P<0.05$.

${ }^{3}$ Value for full statistical model that incorporated all 3 treatments and 5 blocks ( 5 replicate cheesemaking days). ${ }^{4} \mathrm{RF}=$ fat recovered in cheese, determined experimentally from cheese trials.

${ }^{5} \mathrm{ND}=$ not determined.

${ }^{6} \mathrm{RC}=$ casein recovered in cheese, calculated as described by Govindasamy-Lucey et al. (2006). The calculated RC values for control, 89:100 CN:TP, and 95:100 CN:TP cheeses were 0.947, 0.942, and 0.953, respectively. Thus, all calculations were carried out using an average $\mathrm{RC}$ value of 0.95 for all the cheeses.

${ }^{7} \mathrm{RS}=$ recovery of non-CN, nonfat solids in cheese, calculated as described in Govindasamy-Lucey et al. (2006). ${ }^{8}$ Actual yield, determined experimentally from cheese trials, was calculated for each vat of cheese as the weight of cheese divided by the weight of the original cheese milk (including the amount of cultures added during cheese manufacture), multiplied by 100 .

${ }^{9}$ Van Slyke cheese yield was calculated using Equation [1], using milk and cheese composition data given in Table 2. 


\section{Nutritional Analysis of Cheese}

The nutritional analysis of the 3 cheese treatments is shown in Table 7. Cheeses made with MF treatment had slightly higher fat contents and calories from fat, in agreement with the cheese compositional results (Table $2)$. An increase in vitamin A content with MF treatment was detectable, also likely due to the slightly higher fat content in this cheese, as vitamin $\mathrm{A}$ is a fat-soluble vitamin. The potassium content was similar (0.10\%) between all 3 cheese treatments (Table 2). The sodium content was slightly lower in the 95:100 CN:TP cheese. One possible explanation is that the MF treatment resulted in a slight increase in cheese yield, but because all curds were salted at a constant milk volume, the MF cheeses probably received less salt compared with the control. No other significant differences were detectable in the nutritional quality of the 3 cheese treatments, indicating that MF did not cause a detrimental change in the nutritional properties of cheese.

\section{Insoluble Calcium Content in Cheeses}

Figure 1 shows the changes in the amount of INSOL Ca in the cheeses during ripening. The INSOL Ca content did not significantly differ between treatments but did slightly decrease over time (Table 4), in agreement with previous studies on Cheddar cheese (Hassan et al., 2004). A close relationship exists between the $\mathrm{pH}$ of the cheese and the INSOL Ca content. A low $\mathrm{pH}$ value in cheese causes INSOL Ca to solubilize. All cheeses were manufactured with an identical process, so the rate of acidification was similar between cheeses. The $\mathrm{pH}$ values and lactic acid contents of the cheeses were not significantly influenced by treatment (Table 4) and were similar throughout ripening (Table 3), which helped to produce comparable rates of dissolution of calcium phosphate.

\section{Proteolysis}

Changes in $\mathrm{pH}$ 4.6-soluble nitrogen during ripening are shown in Figure 2. No significant difference occurred in the amount of $\mathrm{pH} 4.6$-soluble nitrogen between the 3 cheese treatments (Table 4). The amount of $\mathrm{pH}$ 4.6-soluble nitrogen as a percentage of total nitrogen increased with ripening (Figure 2), as intact CN was broken down. Primary proteolysis is the degradation of CN by proteolytic enzymes, such as chymosin and the indigenous milk protease plasmin (Ivens et al., 2017). Proteolysis was further analyzed after 6 mo of ripening time, using urea-PAGE (Figure 3). No visual difference in the degradation profile of $\mathrm{CN}$ was detectable between treatments. Generally, chymosin hydrolyzes $\alpha_{\mathrm{S} 1}-\mathrm{CN}$ during primary proteolysis. In Cheddar cheese, $\beta-\mathrm{CN}$ is relatively resistant to chymosin hydrolysis but

Table 7. Nutritional analysis (performed at $1 \mathrm{~d}$ of ripening) of Cheddar cheeses that had various levels of whey protein depletion ${ }^{1}$

\begin{tabular}{|c|c|c|c|c|c|}
\hline \multirow[b]{2}{*}{ Nutritional component } & \multicolumn{3}{|c|}{ Treatment $^{2}$} & \multirow[b]{2}{*}{ SEM } & \multirow[b]{2}{*}{$P$-value } \\
\hline & Control & 89:100 CN:TP & 95:100 CN:TP & & \\
\hline Calories (cal/100 g of cheese) & $403^{\mathrm{a}}$ & $405^{\mathrm{a}}$ & $408^{\mathrm{a}}$ & 1.54 & 0.22 \\
\hline Calories from fat (cal/100 g of cheese) & $294^{\mathrm{b}}$ & $298^{\mathrm{a}}$ & $301^{\mathrm{a}}$ & 1.07 & $<0.05$ \\
\hline Fat by acid hydrolysis (\%) & $32.7^{\mathrm{b}}$ & $33.1^{\mathrm{ba}}$ & $33.4^{\mathrm{a}}$ & 0.13 & $<0.05$ \\
\hline Carbohydrates $(\%)$ & $2.03^{\mathrm{a}}$ & $1.57^{\mathrm{a}}$ & $1.47^{\mathrm{a}}$ & 0.26 & 0.29 \\
\hline $\operatorname{Protein}^{4}(\%)$ & $25.4^{\mathrm{a}}$ & $25.2^{\mathrm{a}}$ & $25.3^{\mathrm{a}}$ & 0.14 & $<0.05$ \\
\hline Ash (\%) & $4.00^{\mathrm{a}}$ & $3.92^{\mathrm{a}}$ & $3.71^{\mathrm{a}}$ & 0.08 & 0.13 \\
\hline Moisture (\%) & $35.9^{\mathrm{a}}$ & $36.2^{\mathrm{a}}$ & $36.1^{\mathrm{a}}$ & 0.31 & 0.38 \\
\hline Vitamin $\mathrm{A}$ as retinol (IU/100 $\mathrm{g}$ of cheese) & $875^{\mathrm{b}}$ & $892^{\text {ba }}$ & $923^{\mathrm{a}}$ & 10.68 & $<0.01$ \\
\hline Vitamin C (mg/100 g of cheese) & $<1^{\mathrm{a}}$ & $<1^{\mathrm{a}}$ & $<1^{\mathrm{a}}$ & $\mathrm{ND}^{5}$ & $\mathrm{ND}$ \\
\hline Calcium (mg/100 g of cheese) & $806^{\mathrm{a}}$ & $795^{\mathrm{a}}$ & $802^{\mathrm{a}}$ & 4.44 & 0.18 \\
\hline Iron $(\mathrm{mg} / 100 \mathrm{~g}$ of cheese) & $<0.38^{\mathrm{a}}$ & $<0.38^{\mathrm{a}}$ & $<0.39^{\mathrm{a}}$ & ND & $\mathrm{ND}$ \\
\hline Sodium (mg/100 g of cheese) & $764^{\mathrm{a}}$ & $709^{\text {ba }}$ & $628^{\mathrm{b}}$ & 21.17 & $<0.05$ \\
\hline
\end{tabular}

$\overline{\mathrm{a}, \mathrm{b}}$ Means within the same row not sharing a common superscript differ $(P<0.05)$.

${ }^{1}$ Values represent the means of 3 replicates for each treatment.

${ }^{2}$ The means of the 3 main treatments [different ratios of casein to true protein (TP): control, 89:100 CN:TP, 95:100 CN:TP] were analyzed using ANOVA of PROC GLM in SAS (version 9.1; SAS Institute Inc., Cary, $\mathrm{NC}$ ). Duncan's multiple-comparison test was used to evaluate differences in the treatments at a significance level of $P<0.05$.

${ }^{3}$ Values for full statistical model that incorporated all 3 treatments and 3 blocks (3 replicate cheesemaking days).

${ }^{4}$ Total $\% \mathrm{~N} \times 6.38$.

${ }^{5} \mathrm{ND}=$ not determined. 
is hydrolyzed by plasmin (Ivens et al., 2017). In all 3 cheeses, $\beta-\mathrm{CN}$ was hydrolyzed by plasmin into $\beta-\mathrm{CN}$ $\mathrm{f}(29-209), \quad \beta-\mathrm{CN} \mathrm{f}(106-209), \quad \beta-\mathrm{CN} \mathrm{f}(108-209)$, and $\beta-\mathrm{CN} \mathrm{f}(1-189 / 192)$. $\beta$-CN $\mathrm{f}(1-189 / 192)$ is very hydrophobic and contributes to bitterness in cheese (Bansal et al., 2009). Previous studies have concluded that cheeses made from UF concentrated milk had slower proteolysis, likely due to some type of inhibition of rennet or plasmin activity (Lelievre and Lawrence, 1988; Bech, 1993). Concentration of milk by MF could also potentially concentrate proteinase-peptidase inhibitors (Govindasamy-Lucey et al., 2007). Aaltonen and Ollikainen (2011) reported that MF/DF of milk enhanced plasmin activity in milk, due to the reduction in the $\beta$-LG concentration (which inhibits plasmin). The similar proteolysis levels in our cheeses suggests that any potential inhibition of rennet or plasmin might occur only at higher residual WP levels in cheese (our cheeses had WP levels $\leq 0.11 \%$ ).

\section{Textural and Rheological Properties}

The textural properties (hardness) of cheeses during ripening are shown in Figure 4. Treatment did not significantly affect TPA hardness (Table 4). However, TPA hardness did significantly decrease within the first $90 \mathrm{~d}$ of ripening but hardly changed thereafter (Figure 4). This decrease in hardness over ripening time was expected, as it is typical for Cheddar cheese (Lucey et al., 2003). Similarly, Neocleous et al. (2002b) reported a

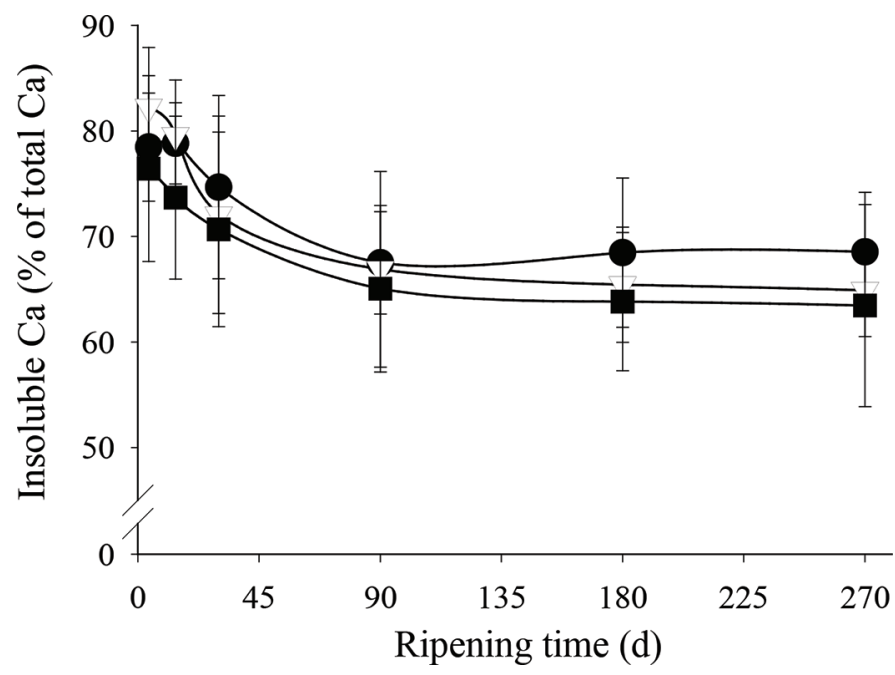

Figure 1. Insoluble calcium content, expressed as a percentage of total calcium, for Cheddar cheeses made with various levels of whey protein depletion; control $(\bullet)$, 89:100 CN:true protein (TP; $\nabla)$, and 95:100 CN:TP (ם) Cheddar cheeses during ripening. Error bars represent $\mathrm{SD}(\mathrm{n}=5)$.

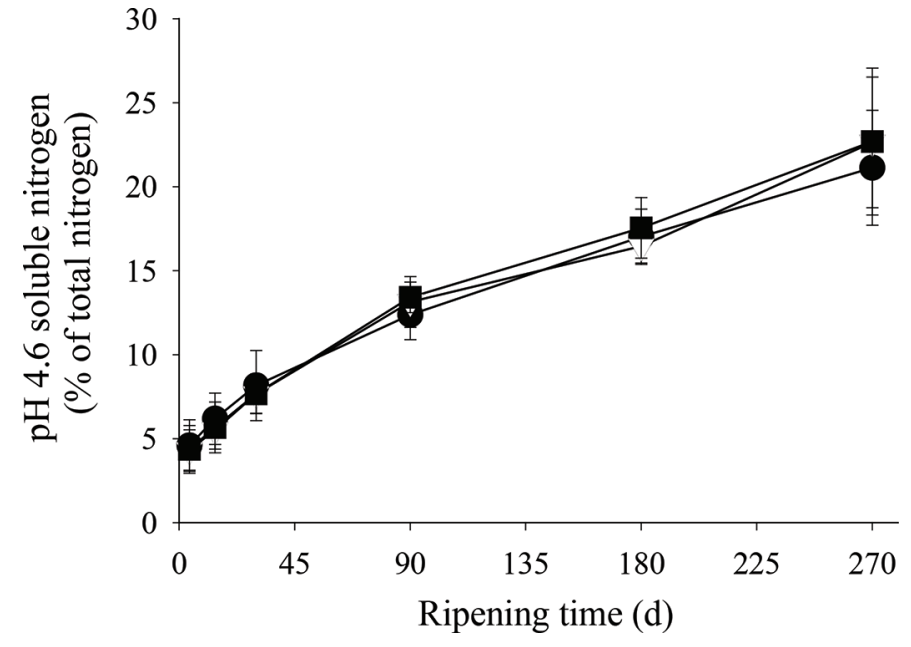

Figure 2. $\mathrm{pH}$ 4.6-soluble nitrogen as a percentage of total nitrogen for Cheddar cheeses made with various levels of whey protein depletion; control $(\bullet)$, 89:100 CN:true protein (TP; $\nabla)$, and 95:100 CN:TP $(\square)$ Cheddar cheeses during ripening. Error bars represent SD $(\mathrm{n}=5)$

slight decrease in the hardness of Cheddar cheese up to $30 \mathrm{~d}$ of ripening; thereafter, hardness hardly changed. The similarity in hardness between cheese treatments can be attributed to samples having similar compositions (Table 2), $\mathrm{pH}$ values (Table 3), INSOL Ca contents (Figure 1), and proteolysis (Figure 2).

Minor but significant differences were observed in the $\mathrm{LT}_{\max }$ and melting point (crossover temperature)

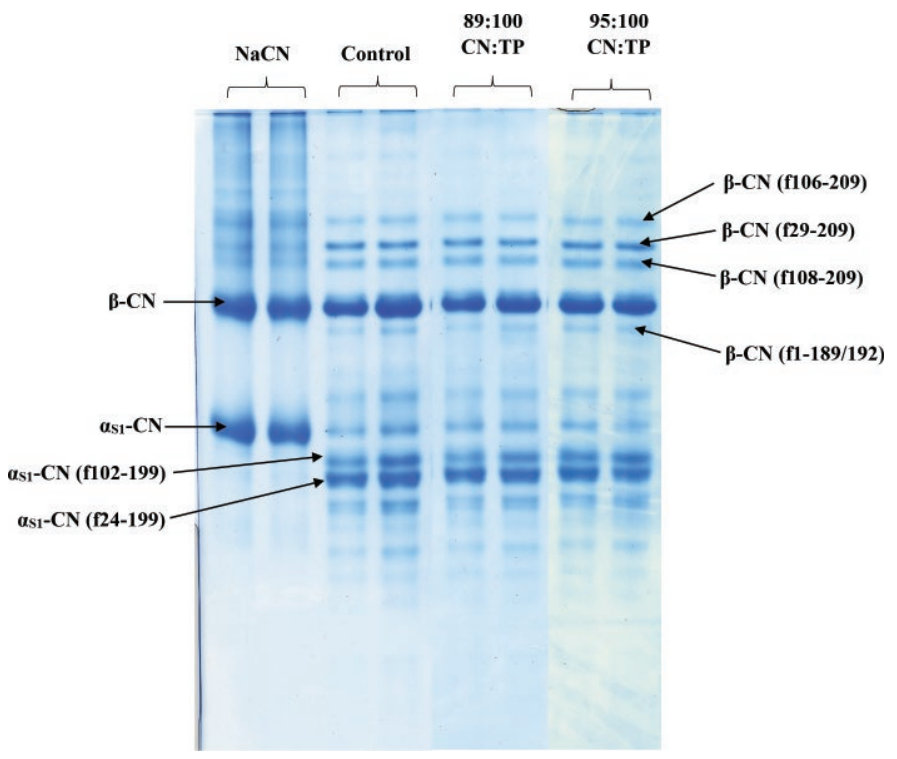

Figure 3. Urea-PAGE electrophoretogram showing the breakdown of casein in Cheddar cheeses made with various levels of whey protein depletion; control, 89:100 CN:true protein (TP), and 95:100 CN:TP Cheddar cheeses after 6 mo of ripening. NaCN is the sodium caseinate standard. 
between the control and experimental cheeses (Figure 5; Table 8). The control cheese had slightly lower $\mathrm{LT}_{\max }$ values than the MF cheeses at $14 \mathrm{~d}$ and 1 mo of ripening (Figure 5a). As ripening continued, we observed no significant difference between the $\mathrm{LT}_{\max }$ values of any of the treatments. The crossover temperature was slightly higher in the control cheese compared with the other cheeses throughout ripening (Figure 5b). The control cheeses had slightly lower fat and higher salt contents (Table 2); these minor compositional differences could have contributed to these small changes in the rheological properties. The $\mathrm{LT}_{\max }$ values for all cheeses increased during ripening as expected (Figure 5a) up to 3 mo, after which no significant change occurred. This indicated that the meltability of all 3 cheeses increased during ripening. The temperature of the crossover point (Figure 5b) decreased with ripening for all 3 cheeses, indicating that less energy was needed for flow as the cheese matrix underwent aging. This was in agreement with previous reports for Cheddar cheese (Lee et al., 2005; Lucey et al., 2005).

Softening of cheese takes place during ripening due to various different mechanisms, which are determined by the types of interactions between $\mathrm{CN}$ that are present in the system (Lucey et al., 2003). During ripening, INSOL Ca phosphate partly dissolves into the serum phase (Figure 1), due to the acidic environment of cheese (Hassan et al., 2004). This reduces the amount of calcium phosphate cross-links between $\mathrm{CN}$ particles and thus makes it easier to flow. This trend, along with

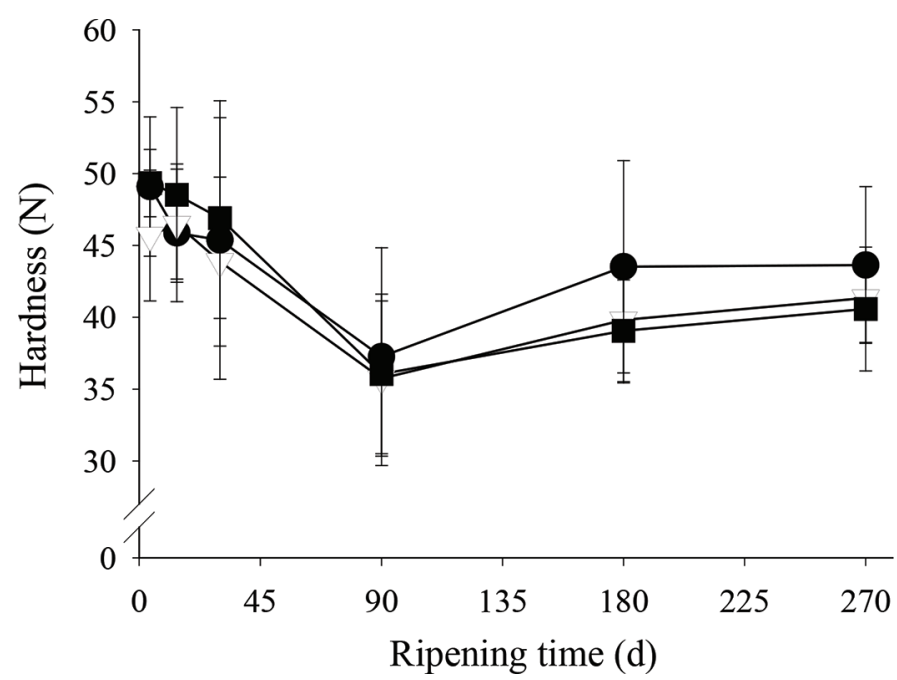

Figure 4. Hardness (N) from texture profile analysis for Cheddar cheeses made with various level of whey protein depletion; control $(\bullet), 89: 100 \mathrm{CN}$ :true protein (TP; $\nabla)$, and 95:100 CN:TP (ם) Cheddar cheeses during ripening. Error bars represent SD $(\mathrm{n}=5)$. a)
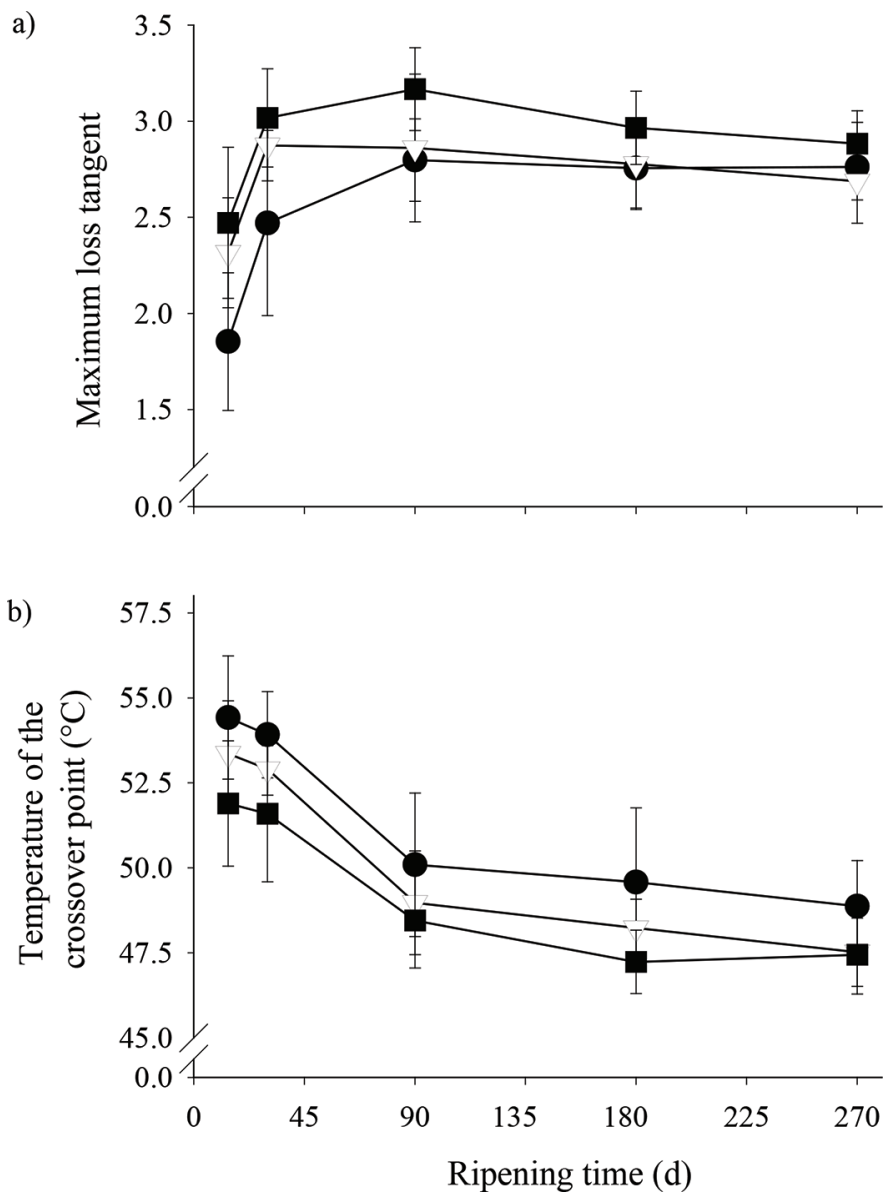

Figure 5. Rheological properties during heating profile of Cheddar cheese samples during ripening. The maximum loss tangent (LT) values (a) and temperature of the crossover point (where LT $=1$; b), for Cheddar cheeses made with various levels of whey protein depletion; control $(\bullet)$, 89:100 CN:true protein $(\mathrm{TP} ; \nabla)$, and 95:100 CN:TP (ם). Error bars represent SD $(\mathrm{n}=5)$.

ongoing proteolysis, likely explains why all the Cheddar cheeses exhibited an increase in $\mathrm{LT}_{\max }$ values during ripening (Lucey et al., 2005).

\section{Sensory Properties}

The sensory textural and flavor attributes of cheeses are shown in Table 9. No sensory attributes except for bitterness differed between the control and experimental cheeses. Panelists detected no significant difference in any textural attributes, such as firmness, cohesiveness, and chewiness, between treatments or over time. This agrees with the TPA hardness trends during cheese aging (Figure 4). Adhesiveness did increase with ripening time (Table 9). Panelists did detect a significant increase in bitterness with ripening time for 
Table 8. Degrees of freedom, statistical significance ( $P$-values), and $\mathrm{R}^{2}$ values for changes in rheological properties and sensory attributes of Cheddar cheeses that had various levels of whey protein depletion during ripening $(\mathrm{n}=5)$

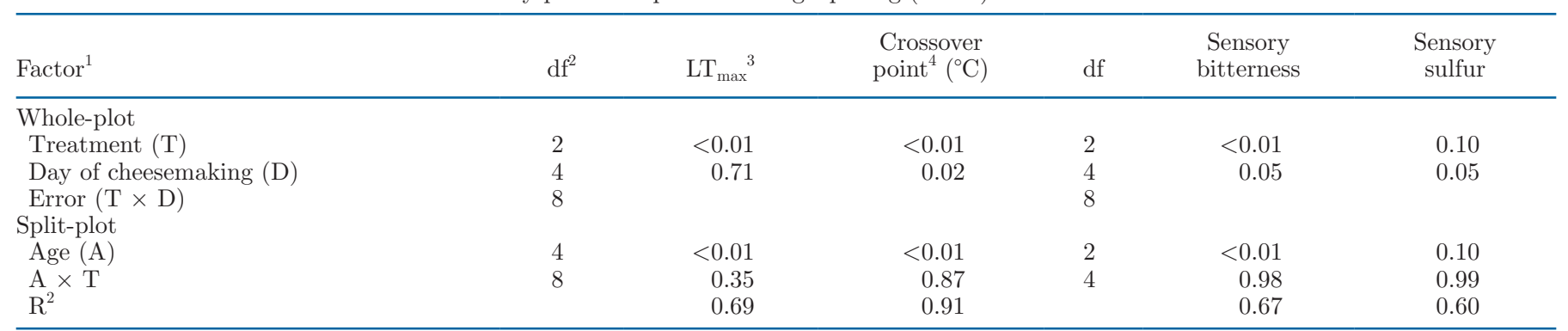

${ }^{1}$ Split-plot design with the 3 treatments analyzed as a discontinuous variable and cheesemaking day blocked $(3 \times 5)$. Subplot included the effect of age of cheese $(\mathrm{A})$ and age $\times$ treatment as variables.

${ }^{2}$ Degrees of freedom differed for variable measurements, as time points for the analyses were different.

${ }^{3}$ Maximum loss tangent.

${ }^{4}$ Temperature at which loss tangent $=1$.

all cheeses (Table 8). A main contributor to the evolution of bitterness in aged Cheddar cheese is the degradation of $\beta-\mathrm{CN}$ into its bitter peptides, such as $\beta-\mathrm{CN}$ f(1-189/192; Lemieux and Simard, 1991; Børsting et al., 2012). The production of this peptide, as observed in the urea-PAGE results (Figure 3), was likely why our sensory panelists detected an increase in cheese bitterness as a function of ripening time. The intensity of bitterness in our cheeses was quite low $(\leq 2.7$ on our 15-point scale; Table 9). The MF cheeses in our study had lower WP and slightly but significantly less bitter intensity compared with the control cheeses throughout ripening (Table 8). No other differences in any other flavor attributes were detected during ripening time. It was previously speculated that a decrease in flavor development in cheeses made from concentrated milk was due to WP inhibiting proteolysis. However, the differences in residual WP content in all our cheeses were small (Table 2); thus, it was not surprising no major differences in the sensory properties occurred.

\section{CONCLUSIONS}

Polymeric MF membranes, when used in conjunction with UF membranes for the DF of MF retentate with UF permeate, can be used to deplete WP from cheese milk without concentrating the $\mathrm{CN}$ content of milk. Removal of WP from milk before cheesemaking provides the opportunity to produce a value-added by-product, milk-derived whey. When Cheddar cheeses were manufactured from these WP-depleted cheese milks, the composition, texture, and nutritional quality were comparable to those of the control cheese. Because the CN content of MF milk was similar to that of the control milk, no adjustments to the cheesemaking process were necessary to achieve cheeses with similar composition and quality. Depletion of WP from milk by
MF did not affect proteolysis, nutritional properties, or sensory attributes during cheese ripening.

Table 9. Sensory textural and flavor attributes (intensities based on a scale of 0-15 points) for cheeses that had various levels of whey protein depletion [control, 89:100 CN:true protein (TP), and 95:100 CN:TP] at ripening times of 3,6 , and $9 \mathrm{mo}(\mathrm{n}=5)$

\begin{tabular}{|c|c|c|c|}
\hline \multirow[b]{2}{*}{ Attribute } & \multicolumn{3}{|c|}{ Treatment } \\
\hline & Control & 89:100 CN:TP & 95:100 CN:TP \\
\hline \multicolumn{4}{|l|}{$3 \mathrm{mo}$} \\
\hline Firmness & $13.6^{\mathrm{a}}$ & $13.3^{\mathrm{a}}$ & $13.5^{\mathrm{a}}$ \\
\hline Cohesiveness & $10.8^{\mathrm{a}}$ & $11.3^{\mathrm{a}}$ & $11.3^{\mathrm{a}}$ \\
\hline Chewiness & $5.4^{\mathrm{a}}$ & $5.3^{\mathrm{a}}$ & $5.4^{\mathrm{a}}$ \\
\hline Adhesiveness & $6.6^{\mathrm{a}}$ & $7.0^{\mathrm{a}}$ & $6.8^{\mathrm{a}}$ \\
\hline Salt & $5.7^{\mathrm{a}}$ & $5.6^{\mathrm{a}}$ & $5.5^{\mathrm{a}}$ \\
\hline Acid & $2.1^{\mathrm{a}}$ & $2.1^{\mathrm{a}}$ & $1.9^{\mathrm{a}}$ \\
\hline Bitter & $1.2^{\mathrm{a}}$ & $0.8^{\mathrm{b}}$ & $0.6^{\mathrm{b}}$ \\
\hline Milkfat & $2.2^{\mathrm{a}}$ & $2.4^{\mathrm{a}}$ & $2.5^{\mathrm{a}}$ \\
\hline Butter & $2.0^{\mathrm{a}}$ & $1.9^{\mathrm{a}}$ & $2.0^{\mathrm{a}}$ \\
\hline Sulfur & $0.9^{\mathrm{a}}$ & $0.7^{\mathrm{a}}$ & $0.8^{\mathrm{a}}$ \\
\hline \multicolumn{4}{|l|}{$6 \mathrm{mo}$} \\
\hline Firmness & $13.4^{\mathrm{a}}$ & $13.3^{\mathrm{a}}$ & $13.3^{\mathrm{a}}$ \\
\hline Cohesiveness & $11.0^{\mathrm{a}}$ & $11.3^{\mathrm{a}}$ & $11.0^{\mathrm{a}}$ \\
\hline Chewiness & $5.7^{\mathrm{a}}$ & $5.8^{\mathrm{a}}$ & $5.7^{\mathrm{a}}$ \\
\hline Adhesiveness & $7.6^{\mathrm{a}}$ & $8.1^{\mathrm{a}}$ & $7.7^{\mathrm{a}}$ \\
\hline Salt & $4.1^{\mathrm{a}}$ & $4.3^{\mathrm{a}}$ & $4.0^{\mathrm{b}}$ \\
\hline Acid & $3.6^{\mathrm{a}}$ & $3.7^{\mathrm{a}}$ & $3.5^{\mathrm{a}}$ \\
\hline Bitter & $2.0^{\mathrm{a}}$ & $1.8^{\mathrm{b}}$ & $1.8^{\mathrm{b}}$ \\
\hline Milkfat & $2.4^{\mathrm{a}}$ & $2.5^{\mathrm{a}}$ & $2.5^{\mathrm{a}}$ \\
\hline Butter & $1.5^{\mathrm{a}}$ & $1.7^{\mathrm{a}}$ & $1.6^{\mathrm{a}}$ \\
\hline Sulfur & $0.3^{\mathrm{a}}$ & $0.5^{\mathrm{a}}$ & $0.4^{\mathrm{a}}$ \\
\hline \multicolumn{4}{|l|}{$9 \mathrm{mo}$} \\
\hline Firmness & $12.8^{\mathrm{a}}$ & $12.7^{\mathrm{a}}$ & $12.7^{\mathrm{a}}$ \\
\hline Cohesiveness & $11.4^{\mathrm{a}}$ & $11.7^{\mathrm{a}}$ & $11.7^{\mathrm{a}}$ \\
\hline Chewiness & $5.7^{\mathrm{a}}$ & $5.7^{\mathrm{a}}$ & $5.7^{\mathrm{a}}$ \\
\hline Adhesiveness & $8.9^{\mathrm{a}}$ & $9.4^{\mathrm{a}}$ & $9.2^{\mathrm{a}}$ \\
\hline Salt & $4.1^{\mathrm{a}}$ & $4.0^{\mathrm{a}}$ & $4.1^{\mathrm{a}}$ \\
\hline Acid & $4.7^{\mathrm{a}}$ & $4.6^{\mathrm{a}}$ & $4.7^{\mathrm{a}}$ \\
\hline Bitter & $2.7^{\mathrm{a}}$ & $2.5^{\mathrm{b}}$ & $2.5^{\mathrm{b}}$ \\
\hline Milkfat & $2.4^{\mathrm{a}}$ & $2.5^{\mathrm{a}}$ & $2.5^{\mathrm{a}}$ \\
\hline Butter & $1.0^{\mathrm{a}}$ & $1.0^{\mathrm{a}}$ & $1.0^{\mathrm{a}}$ \\
\hline Sulfur & $0.6^{\mathrm{a}}$ & $0.5^{\mathrm{a}}$ & $0.5^{\mathrm{a}}$ \\
\hline
\end{tabular}

$\overline{\mathrm{a}, \mathrm{b}}$ Means within the same row not sharing a common superscript differ $(P<0.05)$. 


\section{ACKNOWLEDGMENTS}

The authors thank the personnel from the Center for Dairy Research and University of Wisconsin Dairy Plant (Madison, WI) for their assistance and support in cheesemaking, analytical work, and sensory analyses. The financial support of the Center for Dairy Research Industry Team and the National Dairy Council (Rosemont, IL) is gratefully acknowledged. The authors have not stated any conflicts of interest.

\section{REFERENCES}

Aaltonen, T., and P. Ollikainen. 2011. Effect of microfiltration on plasmin activity. Int. Dairy J. 21:193-197. https://doi.org/10.1016/j .idairyj.2010.12.002.

Andrews, A. T. 1983. Proteinases in normal bovine milk and their action on caseins. J. Dairy Res. 50:45-55. https://doi.org/10.1017/ S0022029900032519.

AOAC International. 2000. Official Methods of Analysis. 17th ed. Association of Analytical Chemists International, Arlington, VA.

AOAC International. 2005. Official Methods of Analysis. 18th ed. Association of Analytical Chemists International, Gaithersburg, MD.

Ardisson-Korat, A. V., and S. S. H. Rizvi. 2004. Vatless manufacturing of low-moisture part-skim Mozzarella cheese from highly concentrated skim milk microfiltration retentates. J. Dairy Sci. 87:36013613. https://doi.org/10.3168/jds.S0022-0302(04)73498-0.

Bansal, N., M. A. Drake, P. Piraino, M. L. Broe, M. Harboe, P. F. Fox, and P. L. H. McSweeney. 2009. Suitability of recombinant camel (Camelus dromedarius) chymosin as a coagulant for Cheddar cheese. Int. Dairy J. 19:510-517. https://doi.org/10.1016/j idairyj.2009.03.010.

Bech, A.-M. 1993. Characterising ripening in UF-cheese. Int. Dairy J. 3:329-342. https://doi.org/10.1016/0958-6946(93)90021-Q.

Bobe, G., D. C. Beitz, A. E. Freeman, and G. L. Lindberg. 1998. Separation and quantification of bovine milk proteins by reversed-phase high-performance liquid chromatography. J. Agric. Food Chem. 46:458-463. https://doi.org/10.1021/jf970499p.

Bonfatti, V., L. Grigoletto, A. Cecchinato, L. Gallo, and P. Carnier. 2008. Validation of a new reversed-phase high performance liquid chromatography method for separation and quantification of bovine milk protein genetic variants. J. Chrom. A 1195:101-106. https://doi.org/10.1016/j.chroma.2008.04.075.

Børsting, M. W., K. B. Qvist, M. Rasmussen, J. Vindelov, F. K. Vogensen, and Y. Ardo. 2012. Impact of selected coagulants and starters on primary proteolysis and amino acid release related to bitterness and structure of reduced-fat Cheddar cheese. Dairy Sci. Technol. 92:593-612. https://doi.org/10.1007/s13594-012-0080-7.

Bourne, M. C. 1978. Texture profile analysis. Food Technol. 32:62-72.

Brandsma, R. L., and S. S. H. Rizvi. 1999. Depletion of whey proteins and calcium by microfiltration of acidified skim milk for cheesemaking. J. Dairy Sci. 82:2063-2069. https://doi.org/10.3168/jds .S0022-0302(99)75447-0.

Brandsma, R. L., and S. S. H. Rizvi. 2001. Manufacture of Mozzarella cheese from highly concentrated skim milk microfiltration retentate depleted of whey proteins. Int. J. Food Sci. Technol. 36:611-624. https://doi.org/10.1046/j.1365-2621.2001.00507.x.

Campbell, R. E., M. C. Adams, M. Drake, and D. M. Barbano. 2013. Effect of bleaching permeate from microfiltered skim milk on $80 \%$ serum protein concentrate. J. Dairy Sci. 96:1387-1400. https://doi .org/10.3168/jds.2012-6053.

Code of Federal Regulations. 2018. Title 21-Food and Drugs, Part 101.9 - Nutrition Labeling of Food. Pages 24-25. Accessed Jul. 20, 2018. https://www.accessdata.fda.gov/scripts/cdrh/cfdocs/cfcfr/ CFRSearch.cfm?fr=101.9.

Coppola, L. E., M. S. Molitor, S. A. Rankin, and J. A. Lucey. 2014. Comparison of milk-derived whey protein concentrates containing various levels of casein. Int. J. Dairy Technol. 67:467-473. https:/ /doi.org/10.1111/1471-0307.12157.

Creamer, L. K., M. Iyer, and J. Lelievre. 1987. Effect of various levels of rennet addition on characteristics of Cheddar cheese made from ultrafiltered milk. N. Z. J. Dairy Sci. Technol. 22:205-214.

Davies, D. T., and J. C. D. White. 1960. The use of ultrafiltration and dialysis in isolating the aqueous phase of milk and in determining the partition of milk constituents between the aqueous and disperse phases. J. Dairy Res. 27:171-190. https://doi.org/10.1017/ S0022029900010256.

FDA. 2005. Cheeses and related cheese products; proposal to permit the use of ultrafiltered milk. A proposed rule by the Food and Drug Administration. Accessed Aug. 1, 2019. https://www .federalregister.gov/documents/2005/10/19/05-20874/cheeses -and-related-cheese-products-proposal-to-permit-the-use-of -ultrafiltered-milk.

Govindasamy-Lucey, S., J. J. Jaeggi, M. E. Johnson, T. Wang, and J. A. Lucey. 2007. Use of cold microfiltration retentates produced with polymeric membranes for standardization of milks for manufacture of pizza cheese. J. Dairy Sci. 90:4552-4568. https://doi .org/10.3168/jds.2007-0128.

Govindasamy-Lucey, S., T. Lin, J. J. Jaeggi, M. E. Johnson, and J. A. Lucey. 2006. Influence of condensed sweet cream buttermilk on the manufacture, yield and functionality of pizza cheese. J. Dairy Sci. 89:454-467. https://doi.org/10.3168/jds.S0022-0302(06)72109-9.

Green, M. L., F. A. Glover, E. M. W. Scurlock, R. J. Marshall, and D. S. Hatfield. 1981. Effect of use of milk concentrated by ultrafiltration on the manufacture and ripening of Cheddar cheese. J. Dairy Res. 48:333-341. https://doi.org/10.1017/S0022029900021762.

Green, W. C., and K. K. Park. 1980. Comparison of AOAC, microwave, and vacuum oven methods for determining total solids in milk. J. Food Prot. 43:782-783. https://doi.org/10.4315/0362 $-028 \mathrm{X}-43.10 .782$.

Guinee, T. P., E. O. Mulholland, J. Kelly, and D. J. O. Callaghan. 2007. Effect of protein-to-fat ratio of milk on the composition, manufacturing efficiency, and yield of Cheddar cheese. J. Dairy Sci. 90:110-123. https://doi.org/10.3168/jds.S0022-0302(07)72613 -9 .

Harper, J., M. Iyer, D. Knighton, and J. Lelievre. 1989. Effects of WP on the proteolysis of Cheddar cheese slurries (A model for the maturation of cheeses made from ultrafiltered milk). J. Dairy Sci. 72:333-341. https://doi.org/10.3168/jds.S0022-0302(89)79114-1.

Hassan, A., M. E. Johnson, and J. A. Lucey. 2004. Changes in the proportions of soluble and insoluble calcium during the ripening of Cheddar cheese. J. Dairy Sci. 87:854-862. https://doi.org/10 .3168/jds.S0022-0302(04)73229-4.

Heino, A. T., J. Uusi-Rauva, P. R. Rantamäki, and O. Tossavainen. 2007. Functional properties of native and cheese whey protein concentrate powders. Int. J. Dairy Technol. 60:277-285. https://doi .org/10.1111/j.1471-0307.2007.00350.x.

Ivens, K. O., J. L. Baumert, R. L. Hutkins, and S. L. Taylor. 2017. Effect of proteolysis during Cheddar cheese aging on the detection of milk protein residues by ELISA. J. Dairy Sci. 100:1629-1639. https://doi.org/10.3168/jds.2016-11649.

Johnson, M. E., and N. F. Olson. 1985. A comparison of available methods for determining salt levels in cheese. J. Dairy Sci. 68:10201024. https://doi.org/10.3168/jds.S0022-0302(85)80924-3.

Kuchroo, C. N., and P. F. Fox. 1982. Soluble nitrogen in Cheddar cheese: Comparison of extraction procedures. Milchwissenschaft $37: 331-335$.

Lee, M. R., M. E. Johnson, and J. A. Lucey. 2005. Impact of modifications in acid development on the insoluble calcium content and rheological properties of Cheddar cheese. J. Dairy Sci. 88:37983809. https://doi.org/10.3168/jds.S0022-0302(05)73065-4.

Lelievre, J., and R. C. Lawrence. 1988. Manufacture of cheese from milk concentrated by ultrafiltration. J. Dairy Res. 55:465-478. https://doi.org/10.1017/S0022029900028727.

Lemieux, L., and R. Simard. 1991. Bitter flavor in dairy products. I. A review of the factors likely to influence its development, mainly in cheese manufacture. Lait 71:599-636. https://doi.org/10.1051/ lait:1991647. 
Lucey, J. A., M. E. Johnson, and D. S. Horne. 2003. Perspectives on the basis of the rheology and texture properties of cheese. J. Dairy Sci. 86:2725-2743. https://doi.org/10.3168/jds.S0022 -0302(03)73869-7.

Lucey, J. A., R. Mishra, A. Hassan, and M. E. Johnson. 2005. Rheological and calcium equilibrium changes during the ripening of Cheddar cheese. Int. Dairy J. 15:645-653. https://doi.org/10 .1016/j.idairyj.2004.08.018.

Marshall, R. T. 1992. Standard Methods for the Examination of Dairy Products. 16th ed. American Public Health Association, Washington, DC.

Meilgaard, M. C., B. T. Carr, and G. V. Civille. 1999. Sensory Evaluation Techniques. 3rd ed. CRC Press, Boca Raton, FL.

Michalski, M. C., V. Briard, and F. Michel. 2001. Optical parameters of milk fat globules for laser light scattering measurements. Lait 81:787-796. https://doi.org/10.1051/lait:2001105.

Michalski, M. C., N. Leconte, V. Briard-Bion, J. Fauquant, J. L. Maubois, and H. Goundedranche. 2006. Microfiltration of raw whole milk to select fractions with different fat globule size distributions: Process optimization and analysis. J. Dairy Sci. 89:3778-3790. https://doi.org/10.3168/jds.S0022-0302(06)72419-5.

Møller, K. K., F. P. Rattray, E. Hoier, and Y. Ardo. 2012. Manufacture and biochemical characteristics during ripening of Cheddar cheese with variable $\mathrm{NaCl}$ and equal moisture content. Dairy Sci. Technol. 92:515-540. https://doi.org/10.1007/s13594-012-0076-3.

Nelson, B. K., and D. M. Barbano. 2005a. A microfiltration process to maximize removal of serum proteins from skim milk before cheese making. J. Dairy Sci. 88:1891-1900. https://doi.org/10.3168/jds .S0022-0302(05)72865-4.

Nelson, B. K., and D. M. Barbano. 2005b. Yield and aging of Cheddar cheeses manufactured from milks with different milk serum protein contents. J. Dairy Sci. 88:4183-4194. https://doi.org/10.3168/jds .S0022-0302(05)73104-0.

Neocleous, M., D. M. Barbano, and M. A. Rudan. 2002a. Impact of low concentration factor microfiltration on milk component recov- ery and Cheddar cheese yield. J. Dairy Sci. 85:2415-2424. https:/ /doi.org/10.3168/jds.S0022-0302(02)74324-5.

Neocleous, M., D. M. Barbano, and M. A. Rudan. 2002b. Impact of low concentration factor microfiltration on the composition and aging of Cheddar cheese. J. Dairy Sci. 85:2425-2437. https://doi .org/10.3168/jds.S0022-0302(02)74325-7.

Pouliot, Y. 2008. Membrane processes in dairy technology-From a simple idea to worldwide panacea. Int. Dairy J. 18:735-740. https: //doi.org/10.1016/j.idairyj.2008.03.005.

Saboya, L. V., and J. Maubois. 2000. Current developments of microfiltration technology in the dairy industry. Lait 80:541-553. https: //doi.org/10.1051/lait:2000144.

Shalabi, S. I., and P. F. Fox. 1987. Electrophoretic analysis of cheese: Comparison of methods. Irish J. Food Sci. Technol. 11:135-151.

United States Department of Agriculture. 1973. Energy Values of Foods: Basis and Derivation. Agriculture Handbook No. 74. Accessed Jul. 20, 2018. https://www.ars.usda.gov/ARSUserFiles/ 80400525/Data/Classics/ah74.pdf.

Van Slyke, L. L., and W. V. Price. 1936. Cheese. Orange Judd Publishing Co. Inc., New York, NY.

Zeppa, G., L. Conterno, and V. Gerbi. 2001. Determination of organic acids, sugars, diacetyl, and acetoin in cheese by high-performance liquid chromatography. J. Agric. Food Chem. 49:2722-2726. https: //doi.org/10.1021/jf0009403.

\section{ORCIDS}

S. Govindasamy-Lucey (ํ) https://orcid.org/0000-0001-9485-7416

M. E. Johnson @ https://orcid.org/0000-0003-2123-6787

Y. Lu ๑ https://orcid.org/0000-0002-2336-1832

J. A. Lucey 주 https://orcid.org/0000-0002-8838-5130 